A revised manuscript submitted to Marine Pollution Bulletin

\title{
Assessment of microbial plankton diversity as an ecological indicator in the NW Mediterranean coast
}

\author{
$\underline{\text { Isabel Ferrera }}{ }^{1,2^{*}}$, Albert Reñé $^{1}$, David Funosas ${ }^{1}$, Jordi Camp ${ }^{1}$, Ramon Massana ${ }^{1}$, Josep \\ M. Gasol ${ }^{1}$ \& Esther Garcés ${ }^{1 *}$ \\ ${ }^{1}$ Departament de Biologia Marina i Oceanografia, Institut de Ciències del Mar, CSIC, \\ Barcelona, Catalunya, Spain \\ ${ }^{2}$ Centro Oceanográfico de Málaga, Instituto Español de Oceanografía, Fuengirola, \\ Málaga, Spain
}

Running title: microbial plankton as an ecological indicator

${ }^{*}$ Correspondence: Isabel Ferrera isabel.ferrera@ieo.es

Centro Oceanográfico de Málaga, Puerto Pesquero s/n, 29640 Fuengirola, Málaga, Spain, tel. (+34) 952197 124, FAX (+34) 952581 388;

*Esther Garcés: esther@icm.csic.es Institut de Ciències del Mar, Pg Marítim de la Barceloneta, 37-49, 08003 Barcelona, Spain, tel. (+34) 932399 500, FAX (+34) 932309555 


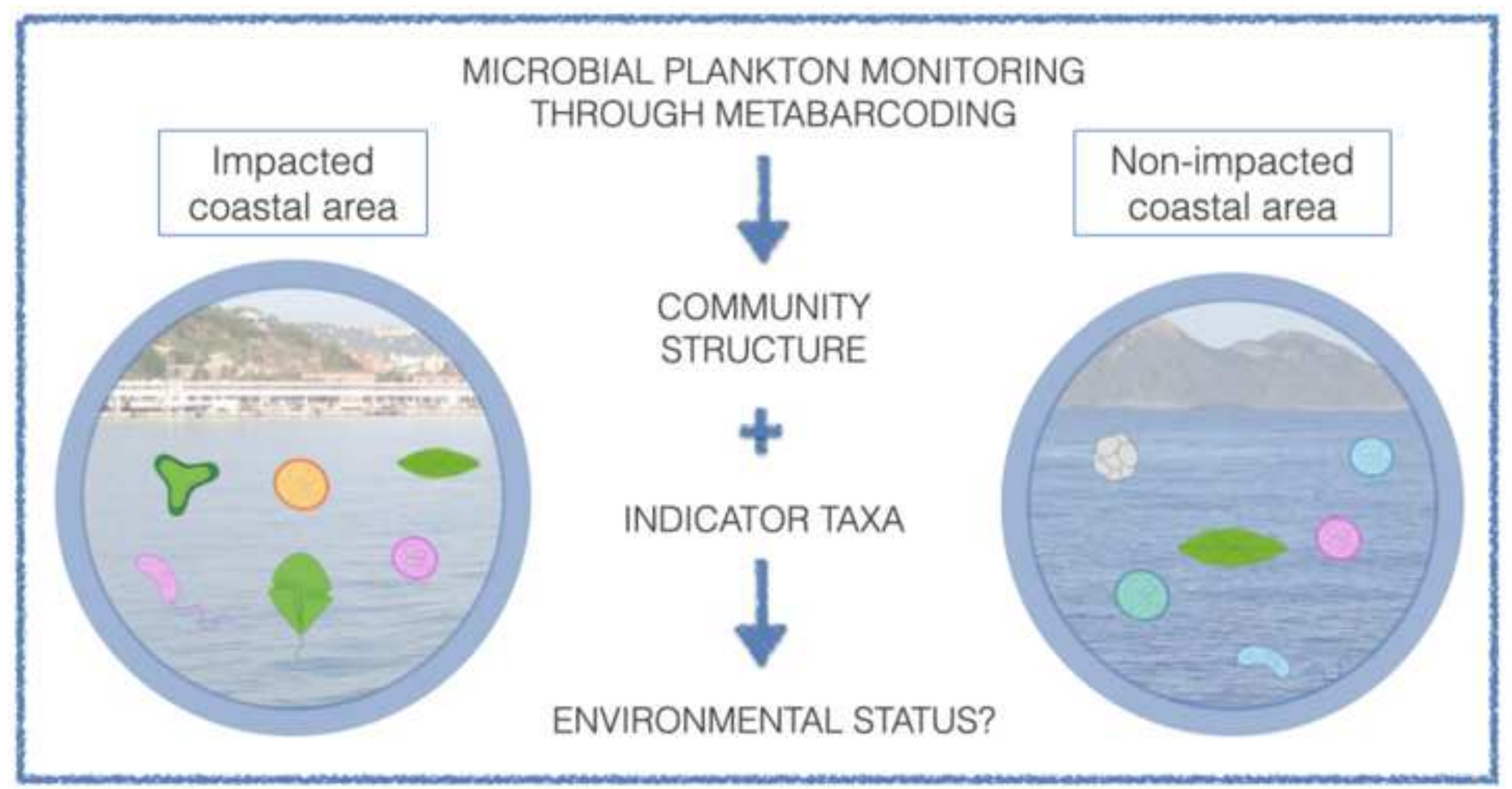

MICROBIAL PLANKTON MONITORING

THROUGH METABARCODING

COMMUNITY

STRUCTURE

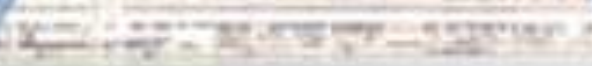

INDICATOR TAXA

ENVIRONMENTAL STATUS?

Non-impacted coastal area 


\section{Research highlights}

- We evaluated microbial pico- and nanoplankton diversity as an ecological indicator in NW Mediterranean coastal waters using metabarcoding of rRNA genes

- Studied samples were subjected to varying degrees of continental pressures

- Diversity metrics from microbial eukaryotic communities displayed more suitability to be used as indicators than those of prokaryotes

- Few microbial planktonic taxa (both from prokaryotes and eukaryotes) showed potential as indicators

- Implementing fast and simple ecological indicators from the diversity of these planktonic components is challenging due to the complexity and dynamics of the pelagic communities 


\section{Abstract}

High-throughput sequencing of microbial assemblages has been proposed as an alternative methodology to the traditional ones used in marine monitoring and environmental assessment. Here, we evaluated pico- and nanoplankton diversity as ecological indicators in NW Mediterranean coastal waters by comparing their diversity in samples subjected to varying degrees of continental pressures. Using metabarcoding of the $16 \mathrm{~S}$ and $18 \mathrm{~S}$ rRNA genes, we explored whether alphadiversity indices, abundance of Operational Taxonomic Units and taxonomic groups (and their ratios) provide information on the ecological quality of coastal waters. Our results revealed that only eukaryotic diversity metrics and a limited number of prokaryotic and eukaryotic taxa displayed potential in assessing continental influences in our surveyed area, resulting thus in a restrained potential of microbial plankton diversity as an ecological indicator. Therefore, incorporating microbial plankton diversity in environmental assessment could not always result in a significant improvement of current marine monitoring strategies.

Keywords: Plankton diversity, high-throughput sequencing, coastal marine monitoring, ecological indicators, anthropogenic pressures, eutrophication 


\section{Introduction}

Oceans provide ecosystem services to society in a myriad of ways, from the regulation of the planet's climate to providing resources for human survival and well-being (Liquete et al., 2013). Human-modified coastal areas are experiencing increasing threats due to a continuously growing human population that accelerates resource use, waste production and environmental degradation. For instance, run-off of pollutants and nutrients arriving to coastal waters may alter natural ecosystems by changing productivity and food web dynamics or shifting species distributions among other impacts of unknown consequences (Halpern et al., 2007; Halpern et al., 2008; Hoegh-Guldberg and Bruno, 2010). All biological components of marine ecosystems may be affected by the consequences of human activities, from microbes to large animals (Davidson et al., 2012; Gall and Thompson, 2015; Cavicchioli et al., 2019). Given the importance of the marine ecosystem for the functioning of our planet and for our own welfare and its vulnerability to human impacts, there is a need to report on its condition and on the responses to the exerted pressures. In fact, numerous initiatives regarding the management of the marine environment have been or are being implemented worldwide in order to protect our seas and oceans (e.g., United Nations Convention on the Law of the Sea, the Marine Strategy Framework Directive in Europe or the Oceans Act in the USA, besides several local initiatives) (Birk et al., 2012).

The European Marine Strategy Framework Directive (MSFD, 2008/56/EC) requires European states to maintain their marine waters in 'Good Environmental Status' (GES). The MSFD includes 11 descriptors of GES: biological diversity, marine food webs, seafloor integrity, non-indigenous species introduction, fisheries, human-induced eutrophication, alteration of hydrographical conditions, concentrations of contaminants, contaminants in fish and other seafood, marine litter and introduction of energy and noise. For each descriptor, the status of the marine environment must be assessed using ecosystem criteria and indicators. There are currently multiple indicators being 
applied to the MSFD, some of them previously used under the European Water Framework Directive (WFD; 2000/60/EC), such as phytoplankton abundance and zoobenthos species composition, for eutrophication and biodiversity respectively (Borja et al., 2010; Camp et al., 2018). However, in the first case for example, the complexity of interactions between phytoplankton structure and physical, chemical and biological factors hinders the establishment of well-defined relationships between pressures and impacts, and therefore, effective management strategies. In fact, initial assessments during the first implementation phase of the MSFD revealed a general lack of operational indicators (Hummel et al., 2015) and thus, the need to develop alternative and innovative ones that can be implemented in a simple, fast and cheap manner (Caruso et al., 2015). In this regard, adding genetic diversity in marine monitoring is gaining attention and showing promising results, particularly in sediments. For example, the use of genomicbased indices has been proposed as an alternative to the macrobenthos biotic indices commonly applied to coastal waters (Aylagas et al., 2016; Pawlowski et al., 2018). Moreover, using microbial community composition has recently been considered in biomonitoring beyond the traditional use of fecal microorganisms as indicators of contamination (Caruso et al., 2015; Danovaro et al., 2016).

Marine microbes are essential in marine biogeochemical cycles and vital for the functioning of food webs, besides being substantial contributors to global marine biodiversity (Gasol and Kirchman, 2018). These organisms are known to respond rapidly to perturbations, such as increase in nutrient loads or events of acute contamination (Nogales et al., 2011). Placing microbial communities at the base of management decisions has gained attention in recent years, particularly after the advent of molecular approaches and high-throughput sequencing (HTS) that allow to overcome the limitation of identifying environmental microbes. A new and promising genomic-based microbial index was proven to correlate well with sediment quality and could be used to assess the ecological status of estuarine and coastal sediments (Aylagas et al., 2017). Likewise, diversity surveys of benthic bacterial and protist communities based on DNA sequencing 
seem to be useful in environmental assessments of fish farming, an industry having serious environmental impacts in marine habitats (Pawlowski et al., 2014; Stoeck et al., 2018).

Contrary to sediments, in which pollution is deposited and accumulated over time, pelagic ecosystems are much more dynamic which, comparatively, makes the determination of environmental status potentially more challenging. In fact, despite the increasing knowledge on the composition of plankton communities in recent times, their use for assessment of environmental status in marine waters is only beginning to be explored. Recently, Pearman et al. (2018) evaluated plankton communities in anthropogenically impacted oligotrophic coastal regions of the Red Sea and concluded that studying changes in the composition of microbial communities could be used to complement the existing approaches used to examine the multiple stresses affecting coastal areas. Nonetheless, given the limited information existing for pelagic ecosystems, more studies are required to better evaluate the usefulness of including small planktonic communities in the assessment of anthropogenic impacts in marine ecosystems.

In this study we explore pico- and nanoplankton diversity as an ecological indicator in the North-western Mediterranean coast. Beforehand, we had compared the performance of two distinct HTS methodologies to study marine picoplanktonic biodiversity and explored their use in ecosystem health assessment (Ferrera et al., 2016). This initial study revealed that certain taxa, as well as the ratio between the abundances of some bacterial groups, had potential for being useful indicators. Yet, the study was limited to a single location - the coast of Barcelona - at a single time point and more extensive surveys were needed to further evaluate the robustness of these findings. Here, we have tested the applicability of microorganisms as operational GES indicators in a survey of 6 locations across the Catalan and Balearic coasts subjected to varying degrees of continental pressures. In particular, we have explored whether diversity and richness indices, the relative abundance of OTUs (Operational Taxonomic Units) and taxonomic 
groups, as well as the ratios between the abundances of different planktonic groups respond to coastal impacts thus providing information on the ecological quality of NW Mediterranean coastal waters.

\section{Methods}

\subsection{Study sites.}

Surface water samples were collected from six locations located along the Catalan and Balearic coastal areas (Figure 1) that are representative of the NW Mediterranean coast in terms of geography, demography and socioeconomic activities. The choice of these coastal sites was based on previous characterization of the areas in the context of the Water Framework Directive (Table S1; Flo et al. 2011, 2017, 2019) and on Basterretxea et al. (2018). The six areas covered a variety of continental pressures and putatively receive variable nutrient loads and other pollutants from urban, industrial and agricultural activities (domestic waste, organic and inorganic nutrient enrichment among others). First, four cross-shore transects were undertaken in Palma de Mallorca, L'Estartit, L'Hospitalet de l'Infant and Barcelona. Sampling was conducted in summer (June-July 2014 for the Catalan Coast and July 2015 for the Balearic Coast) when temperatures are warm (see Table 1) and there is a lack of tidal mixing (Basterretxea et al., 2018). Palma $\left(39^{\circ} 32^{\prime} \mathrm{N} 2^{\circ} 43^{\prime} \mathrm{E}\right)$ is an intensive agricultural area in the island of Mallorca with reported nutrient rich groundwater seeps along the shoreline (Rodellas et al., 2014; TovarSánchez et al., 2014). The L'Estartit ( $\left.42^{\circ} 01^{\prime} \mathrm{N} 3^{\circ} 12^{\prime} \mathrm{E}\right)$ coastal area drains from a wetland with some agricultural activity and is also influenced by the Ter river, a low flow nitraterich Mediterranean river. L'Hospitalet de l'Infant $\left(40^{\circ} 58^{\prime} \mathrm{N} 0^{\circ} 54^{\prime} \mathrm{E}\right)$ is a sparsely populated region with dry land agriculture. While groundwater seeps from nearby coastal aquifers (Fernández Ruiz, 2012), nutrient concentrations along the coast are lower than at the previously mentioned agricultural areas. Barcelona is a hypothetically more impacted site since it is a highly developed urban area with a population of $\sim 3.2$ million inhabitants in the metropolitan area. From each of these four sites, $\sim 10$ surface samples were 
collected from the coastline to about 4-6 miles offshore. In the area of Barcelona, two additional cross-shore transects of 5 samples conducted in June and August 2013 around the PUDEM Coastal Ocean Observatory monitoring station (Arin et al., 2013) have been included in this study, one of them corresponding to the samples analyzed in Ferrera et al. (2016). Sampling cross-shore transects could reveal a continental pressure gradient even within samples collected in one area, since those taken near the coast are presumably more prone to be affected than the corresponding offshore samples. Besides these coast-to-offshore samplings, a transect of 4 stations was conducted in July 2014 in the estuarine Alfacs Bay, located in the Ebro Delta (40`38'N 0`43'E). This represents one of the most riverine-influenced areas of the Catalan coast and was selected to include samples subjected to a large agricultural influence.

In addition to these spatial gradients, samples from two time-series monitoring stations covering contrasting urban scenarios were included in the survey. The Blanes Bay Microbial Observatory $\left(41^{\circ} 40^{\prime} \mathrm{N} 2^{\circ} 48^{\prime} \mathrm{E}\right)$ is a coastal oligotrophic site subjected to low anthropogenic pressures (Gasol et al., 2016). The sampling station is located near the town of Blanes of $\sim 40.000$ inhabitants; natural disturbances are not frequent in this site since the closest river flows south of the monitoring station and its discharges are taken away by a predominantly south-west surface current. Samples collected from 2004 to 2013 were available for this study (but we excluded those from 2010-2012 due to construction of a nearby harbor during this period). The second location is the abovementioned PUDEM Station, off the coast of Barcelona. Samples collected at this site in 2014 were available for our study. Although monthly sampling is typically conducted in these two monitoring stations, only samples from June to September were used in the analyses to avoid natural seasonal variability from masking the potential differences found between areas. A total of 93 samples were included in the analyses. Basic environmental data associated to the samples are shown in Table 1.

\subsection{Sample collection}


About $2 \mathrm{~L}$ of $200-\mu \mathrm{m}$ pre-filtered surface seawater were collected and immediately transported to the laboratory where they were sequentially filtered through a $20-\mu \mathrm{m}$ mesh followed by a 3- $\mu \mathrm{m}$ and a $0.2-\mu \mathrm{m}$ pore-size polycarbonate filter (Poretics) using a peristaltic pump. The aim of the serial filtration was to obtain two different microbial size fractions, picoplankton from 0.2 to $3 \mu \mathrm{m}$ and nanoplankton from 3 to $20 \mu \mathrm{m}$. The size filtering separates eukaryotic organisms of different sizes, while in the case of prokaryotes it mostly separates free-living $(0.2-3 \mu \mathrm{m})$ from particle-attached $(3-20 \mu \mathrm{m})$ cells (Acinas et al., 1999). Filters were kept at $-80^{\circ} \mathrm{C}$ until processed. Cells were lysed using lysozyme, proteinase $\mathrm{K}$ and sodium dodecyl sulfate, and nucleic acids were extracted with phenol and concentrated in an Amicon 100 (Millipore), as described in Massana et al. (1997). The DNA was quantified spectrophotometrically (Nanodrop, Thermo Scientific), and a subsample was sent for sequencing to the Research and Testing Laboratory (rtlgenomics.com/).

A suite of environmental parameters was measured during sample collection. Temperature and salinity were measured with a CTD probe, the concentrations of inorganic nutrients were determined spectrophotometrically using an Alliance Evolution II autoanalyzer according to standard procedures (Grasshoff et al., 1983). In addition, distance to the coastline and freshwater content were taken into account in the analyses. Freshwater content was obtained from the salinity in the water in relation to the maximum salinity in the dataset as follows:

Freshwater content $=1000-(1000 * S) / \max (S)$ where $S$ is salinity

\subsection{Sequencing and sequence processing}

Both prokaryotes (i.e. Bacteria) and eukaryotes were amplified from the two size fractions collected. Primers 341F (5'-CCTACGGGNGGCWGCAG-3'; Herlemann et al., 2011) and 806RB (5'-GGACTACNVGGGTWTCTAAT-3'; Apprill et al., 2015) were used to amplify the V3-V4 region of the bacterial 16S rRNA gene, whereas eukaryotic primers TAReuk454FWD1 (5'-CCAGCASCYGCGGTAATTCC-3') and TAReukREV3 (5'- 
ACTTTCGTTCTTGATYRA-3') (Stoeck et al., 2010) were used to amplify the V4 region

of the $18 \mathrm{~S}$ rRNA gene. Amplicons were sequenced in an Illumina MiSeq $2 \times 250$ flow cells following protocols described elsewhere (Cúcio et al., 2016).

Illumina reads of both $16 \mathrm{~S}$ and $18 \mathrm{~S}$ rRNA genes underwent quality filtering before being analyzed through a custom made pipeline (Logares, 2017). Spades software (Nikolenko et al., 2013) was used to correct errors that may had arisen in the sequencing process; R1 (forward) and R2 (reverse) reads were merged using Pear (Nurk et al., 2013) and the resulting sequences were filtered by quality (expected errors per sequence did not exceed 1) with USEARCH. Then, all reads were put into the same direction using a Hidden Markov Model, concatenated, dereplicated with USEARCH and sorted by abundance. Subsequently, reads were clustered into OTUs (Operational Taxonomic Units) using $97 \%$ similarity threshold for prokaryotes and $99 \%$ for eukaryotes, and possible chimeras were filtered using the version 119 of the SILVA SSU non-redundant database as reference. Singletons were also discarded as a pre-emptive measure to remove OTUs putatively deriving from sequencing errors. Next, the OTU table was generated and OTUs were taxonomically classified by using BLAST against SILVA v119 for prokaryotes and an in-house database for eukaryotes (EukaryotesV4 database; Obiol et al., 2020). Subsequently, all OTUs classified as chloroplast, mitochondria or Archaea, in the case of prokaryotes, and Metazoan, Streptophyta or Nucleomorphs in the case of eukaryotes, were removed. After filtering, the OTU reads for each sample were rarefied to 5000 reads and the resulting table was used for the diversity and richness indices, whereas the other analyses were carried out using the OTU table with relative abundances. OTUs were collapsed into the main prokaryotic (i.e. bacterial) and eukaryotic taxonomic groups when needed to explore the relative contribution of each group.

\subsection{Data analyses}

An arcsine, or angular, transformation was applied to the OTU relative abundances in the non-rarefied table. This transformation equals to the inverse sine of the square root 
of the proportion transformed again from radians to a proportion value, or:

$$
2 / \pi * \arcsin (\sqrt{ } p)
$$

where $p$ is the relative abundance of an OTU. The arcsine transformation spreads the ends of the scale while compressing the middle, and is recommended by many statisticians for proportion data, often improving normality (Sokal and Rohlf, 1995).

In order to categorize the stations depending on their degree of anthropic pressure, we used the FLU and FAN methods developed and validated by Flo (2017) in the same study area. FLU is an abbreviation of FLUviality and FAN is the acronym of phosphate (Fosfat in Catalan), Ammonium, and Nitrite. The approach uses physicochemical variables to assess continental urban and fluvial influences in a given site. The method is based on the following assumptions: i) the main pressures on coastal waters are continental influences, which are linked to freshwater inflows and to the nutrients they release into coastal waters, ii) continental influences, through their nutrient contributions, trigger the production of chlorophyll a in coastal waters, which may enhance eutrophication, and iii) continental influences on coastal waters can be of urban or fluvial origin. The FLU index, computed mainly based on silicate and nitrate levels as well as on freshwater content (FWC) describes a gradient related to fluvial continental influences. The FAN index mainly reflects phosphate, ammonium, and nitrite levels and describes a gradient related to urban continental influences of anthropogenic origin. The method was validated along the Catalan coast using a large time series dataset (1994-2014, $\mathrm{N}=18,102$ ) and can be applied at different spatial and temporal scales and is reproducible, allowing comparisons across geographical areas and study periods. The indices were calculated following the formulas from Flo (2017):

FLU index $=0.86{ }^{\star} \mathrm{NO}_{3}-0.37^{\star} \mathrm{NO}_{2}-0.52^{\star} \mathrm{NH}_{4}-0.89^{\star} \mathrm{PO}_{4}+1.15^{\star} \mathrm{SiO}_{4}+0.87^{\star} \mathrm{FWC}-2.00$

FAN index $=-0.19^{\star} \mathrm{NO}_{3}+2.86^{\star} \mathrm{NO}_{2}+1.42^{\star} \mathrm{NH}_{4}+2.91^{\star} \mathrm{PO}_{4}-0.27^{\star} \mathrm{SiO}_{4}-0.35^{\star} \mathrm{FWC}-0.60$

Based on the values of both indices, all samples were classified into three categories 
(Low, Medium and High) according to the quartile to which they belong. The values belonging to the first quartile were classified as Low, the ones belonging to the two central quartiles as Medium and the ones belonging to the highest quartile were classified as High (Figure S1).

Statistical analyses were performed using the $R$ statistical software ( $R$ Development Core Team, 2015) and the packages ggplot2, reshape2, phyloseq, magrittr, labdsv, tidyverse, dendextend, ggfortify, FactoMineR, lubridate, vegan and dplyr. The Shannon and Chao1 indices, for diversity and for richness estimation respectively (Magurran 1988; Chao and Lee, 1992), were calculated for both plankton size fractions of prokaryotes and eukaryotes. These indices are of common use and were obtained through the phyloseq package in R. The values were grouped according to the FLU and FAN index category that each sample falls into. For community structure analyses, we used the vegan package. A dissimilarity matrix (Bray-Curtis) was constructed based on the rarefied OTU table with the vegdist function. Patterns of community structure were visualized using metaMDS. Additionally, we tested for significant relationships between environmental variables and the nMDS ordination of samples using the envfit function. Permutational tests ( $\underline{\text { adonis}})$ were employed to examine community differences among sampling areas. Potential indicator OTUs or taxonomic groups were also explored by calculating the Pearson correlation coefficient between the relative abundance of each OTU or taxonomic group and the FLU and FAN values, as well as the concentration of nutrients in the water samples. Additionally, Indicator Value (IndVal; Dufrêne and Legendre, 1997), which use species (or OTU) fidelity and relative abundance to identify indicator species, were calculated in order to identify potential indicators for the three categories (Low, Medium or High) of the impact indices. The tests were carried out separately for each size fraction, since organisms belonging to the same taxonomic group but with substantially different sizes or lifestyles could respond differently to environmental changes. The $p$ values were corrected through the Holm-Bonferroni method (Holm, 1979) for the number of taxonomic units being tested for potential correlations with nutrient concentrations or impact 
index values, in order to avoid having spurious significant $p$-values as a consequence of the high number of tests performed. The IndVal results were capped at $p$-value $<0.05$ and IndVal value $>0.3$, since this is the value that has been proposed as a threshold for indicating habitat specialization (Dufrêne and Legendre 1997). The results were also filtered by the relative abundance of the analyzed OTUs or taxonomic groups, with a threshold of $0.4 \%$ as in Ferrera et al. (2016) since the potential as indicator species of rare OTUs is questionable considering the differences found between sequencing methods (Ferrera et al. 2016) and the known biases of the PCR-based methodologies (Polz and Cavanaugh, 1998). Analysis of variance was used to test for differences in the relative abundance of different taxa depending on the impact index category. $P$ values were adjusted by the number of ANOVAs performed. Sequence data has been submitted to the European Nucleotide Archive (www.ebi.ac.uk/ena) under accession numbers PRJEB23788, PRJEB38773, PRJEB38800 and PRJEB38808.

\section{Results}

Impact indices. For the purpose of categorizing the samples in relation to continental pressures, two impact indices were calculated: the FLU and the FAN indices (Table 1). The values were plotted by location (Figure 2); FLU and FAN values were significantly different among sampling locations (ANOVA, $p$ values $=1.76 \mathrm{e}^{-11}$ and $2.88 \mathrm{e}^{-13}$ respectively). In particular, samples from Alfacs, L'Estartit and L'Hospitalet de l'Infant displayed higher FLU values than other locations. These sites are located in areas with either riverine (Alfacs, L'Estartit) or groundwater (Alfacs, L'Hospitalet de l'Infant) influence. At the same time, these three locations displayed much lower FAN values than in other locations, being the differences statistically significant from those from Barcelona and Blanes (Tukey HSD test at $p<0.05$ ). FAN values for Barcelona and Blanes were however within the same range despite the diverging continental pressures expected. Palma presented somewhat intermediate FLU and FAN values (indicating a mixed influence of urban and freshwater pressures). The values of the indices were pooled and classified into Low, Medium and High categories (see Materials and 
Methods, Figure S1) in order to explore the response of the biological variables (i.e. diversity data) in relation to these indices. Most samples from Alfacs, L'Estartit and L'Hospitalet de l'Infant fell within the High category of the FLU index. Barcelona and Palma samples belonged mainly to the Medium impact category. For Blanes, FLU values were variable; while many samples fell into the Low category, some of them also belonged to the Medium or High categories. The opposite trend was observed for the FAN index from Alfacs, L'Estartit and L'Hospitalet de l'Infant that fell mostly in the Low FAN category. As for the FLU index, Palma samples were categorized as Medium FAN impact, while Barcelona and Blanes samples were distributed between the Medium and High FAN impact categories.

Diversity indices. Biological diversity is one of the descriptors included in the European MSFD for the assessment of 'Good Environmental Status'. We thus explored whether common alphadiversity metrics (i.e. Chao1 index for richness and Shannon index for diversity) were related to the computed FLU and FAN indices (Figures 3 and 4). For prokaryotes, Chao1 and Shannon indices displayed higher values for the particleattached bacteria (nanoplankton fraction) than for the free-living one (picoplankton), regardless of the category of the FLU or FAN indices. The response of the alphadiversity indices to the degree of impact estimated by the FLU and FAN indices was however little. No significant differences were found for alphadiversity indices of prokaryotes (neither for the free-living nor for the particle-attached bacteria) as a function of the FLU or FAN categories (ANOVA, $p>0.05$, Figure $3 a$ ). Compared to prokaryotes, eukaryotes displayed overall higher values of alphadiversity. Eukaryotic nanoplankton presented higher Chao1 values than picoplankton but this trend was not observed for the Shannon diversity values (Figure 4). As for the differences in relation to the impact indices, greater differences were observed for eukaryotes than for prokaryotes. In particular, significant differences were found for picoplankton in Chao1 and Shannon indices for the different categories of the FLU (ANOVA, $p=5.82 \mathrm{e}^{-03}$ and $p=9.36 \mathrm{e}^{-04}$ respectively) and FAN (ANOVA, $p=4.59 \mathrm{e}^{-05}$ and $p=3.50 \mathrm{e}^{-05}$ respectively) indices whereas these differences 
were only significant for Shannon diversity in the nanoplankton fraction (ANOVA, $p=2.85 \mathrm{e}^{-03}$ and $p=4.22 \mathrm{e}^{-04}$ for FLU and FAN, respectively). Interestingly, contrary to prokaryotes, lower values of alphadiversity corresponded to higher values of the FLU index while the FAN categories followed the opposite trend.

Community structure. Non-metric multidimensional scaling indicated that the sampling area had a certain role in structuring plankton assemblages in all components (prokaryotic and eukaryotic) and size fractions (pico- and nanoplankton) analysed here (Figure S2), an observation confirmed by permutational analyses that showed that it explained $22 \%$ to $36 \%$ of the variation $(p<0.001)$. For prokaryotic communities, samples from Barcelona generally showed the least delineated clustering while communities from L'Hospitalet de l'Infant formed the most defined one. A different pattern was observed for eukaryotes; while eukaryotic picoplankton from Blanes showed the highest dissimilarity to other communities, eukaryotic nanoplankton assemblages from this sampling station were similar to those from other areas, while those assemblages from Barcelona were highly dissimilar. Fitting of environmental factors to the nMDS ordination revealed an effect of various variables. While silicate and nitrate concentration correlated significantly to the structure of all assemblages analyzed, phosphate concentration and temperature only showed significant correlation with particular assemblages. The FAN index correlated with prokaryotes from the nanoplankton and the eukaryotic picoplankton fractions, while the FLU index was significant only with the former. No significant correlations were found between these impact indices and the rest of assemblages (Figure S2).

Potential indicator taxa. Given that microbes respond rapidly to variations in environmental conditions, including nutrient inputs, we explored whether the relative abundances of the occurring taxa were related to the impact indices, both at the broad taxonomic group and at the OTU level. Figure 5 shows the relative contribution of major prokaryotic and eukaryotic taxa to planktonic community structure grouped by the category of the impact indices that the samples belong to (Low, Medium or High 
categories of FLU and FAN). Although no major changes in the taxonomic composition of the samples were observed regardless of their category, analysis of variance revealed that significant differences existed for the Actinobacteria, Rickettsiales (Alphaproteobacteria) and Sphingobacteriia (Bateroidetes) in relation to the FLU and FAN categories (Figure S3, Table S2). Within the eukaryotic taxa, analyses of variance only revealed significant differences in the abundance of the Basal Fungi (Opisthokonta) in the nanoplankton size in relation to the impact indices. Besides, we tested for differences at the OTU level and only found positive correlations between a nanoeukaryotic OTU affiliated to Gymnodinium litoralis (Dinoflagellata) and the concentrations of phosphate, nitrate and silicate $\left(\mathrm{N}=36, R>0.5, p<1 \mathrm{e}^{-13}\right.$, Table S3).

We further explored potential 'indicator taxa' through the Indicator Value (IndVal) from Dufrêne and Legendre (1997). This value identifies indicator taxa fidelity and relative abundance and is a popular measure to express taxa importance in community ecology. Likewise, its potential to reflect environmental quality has been explored in biodiversity surveys (Ferrera et al., 2016; Lumbreras et al., 2016; Cordier et al., 2020). A total of 9 prokaryotic and 6 eukaryotic taxonomic groups were found with significant IndVal and relative abundances higher than $0.4 \%$ (Table 2). These groups have explanatory power mostly for either the Low and High categories of the impact indices, and most often for the FLU index (Table 2). More significant IndVal were detected among the prokaryotes than the eukaryotes. Moreover, significant IndVal were found in the two analyzed size fractions of the prokaryotic dataset but only in the picoplankton fraction of the eukaryotes. Most prokaryotic indicator taxa of the High FLU impact were at the same time indicators of the Low FAN index category (i.e., the Actinobacteria, Planctomycetes and Sphingobacteriia). Additionally, the Flavobacteriia were indicator only for the FLU index (Medium impact). For eukaryotes, the Rhizaria (Cercozoa) and Stramenopiles (MAST-3 and MAST-4) appeared as potential indicators for the Low category of the FLU index while the Telonema (Hacrobia) were indicator for the High category of this index and, at the same time, for the Low FAN impact category. 
Besides the concept of indicator species or taxa, the potential of quality indicators based on the ratio of different taxa was investigated. In particular, we explored the ratios of the bacterial groups Alphaproteobacteria / Gammaproteobacteria, Alteromonas / SAR11, and Alteromonas + Oceanospirillales / SAR11 that had been proposed in our previous work (Ferrera et al., 2016) together with various alternative potential indices based on the abundance of those groups that appeared as indicator taxa. We found that, from all those tested, only the ratio Actinobacteria / Rickettsiales, calculated by dividing the relative abundances of Actinobacteria by that of Rickettsiales in the picoplankton fraction, was higher at high FLU values (Figure 6). No ratios with indicator potential were found within the eukaryotes.

\section{Discussion}

We explored the informative potential of pico- and nanoplankton communities for environmental status assessment using pelagic samples collected from diverse areas of the NW Mediterranean. As recently reviewed by Cordier et al. (2020), various strategies to explore indicators based on environmental genetic data exist. Here, we explored the socalled 'structural community metrics strategy' by examining the potential of diversity and richness indices, and the 'de novo strategy' aimed at discovering new indicators of environmental status in the water column by analyzing the abundances of OTUs and taxonomic groups (and their ratios). To do so, we classified the sampled stations based on the FLU and FAN impact indices, which indicate the origin of the land influences to the coast, derived from physicochemical variables as previously described (Flo 2017) and explored whether the biological variables responded to them. These indices were developed to distinguish between natural and cultural eutrophication, which is key to management planning. The FLU index clearly distinguished samples from Alfacs Bay and L'Estartit, both influenced by rivers, as well as from L'Hospitalet de l'Infant which could be explained by the presence of nearby groundwater seeps (Fernández-Ruiz 2012, Basterretxea et al., 2018). Likewise, the FAN values were overall different among sites but varied slightly between Blanes and Barcelona despite these are a small and a large 
city, respectively. In any case, the highest values were found for samples off the coast of Barcelona, particularly those closest to shore (Figure S4). Contrarily, samples collected at $200 \mathrm{~m}$ from the coast line of Barcelona showed values within the range of low populated areas (Figure S4). The lack of differences between these sites may be related to the implementation of policies to reduce the impact of urban areas on coastal systems (i.e., wastewater treatment plants, sewage management, etc.) that combined with natural processes challenge the reliable discrimination between natural variability and human effects in the water column. For instance, one station statistically considered to be in good environmental status can episodically present low values of water quality (in our case would be reflected by high FAN values) that fall within the range of the best values from another location considered to be in bad environmental status, and vice versa. The large variability of FAN values from for Blanes and Barcelona could be examples of this scenario.

The measurement of species diversity of an ecosystem has been proposed as a useful tool for assessing the impacts of human activities on marine ecosystems. The strategy based on community metrics aims at discovering and understanding the ecological processes shaping communities and their response to disturbances (see Cordier et al., 2020). Actually, the results of our previous work (Ferrera et al., 2017) indicated that it could be worth exploring the links between microbial diversity and environmental status of coastal waters. Here, we found that both Chao1 and Shannon indices from eukaryotic communities showed power as indicators for assessing continental influences. These findings are contrary to those reported by Pearman et al. (2018) that found no differences in alphadiversity in a study assessing plankton community in anthropogenic-impacted coastal regions of the Red Sea. Likewise, opposed results have been reported in marine sediments; alphadiversity has been found to decrease in bacterial communities impacted by aquaculture (Stoeck et al., 2018) but disturbances can also trigger increases in bacterial diversity (Galand et al., 2016). These results evidence that the complexity of microbial plankton communities challenges the search for indicators of GES in the water column and suggest that the 
implementation of diversity metrics for environmental monitoring should be conducted in combination with other community and environmental characteristics.

Community structure analyses revealed an influence of the sampling area and of certain environmental factors on the structuring of plankton assemblages. Moreover, differences in the abundance of certain taxa were observed in relation to nutrient values and impact indices. Both prokaryotes and eukaryotes showed potential as indicators. Within the prokaryotes, the relative abundance of Actinobacteria in the picoplankton displayed the highest Indicator Value, particularly as indicator of the High category of the FLU and the Low FAN impact indices. Actinobacteria, are widely distributed in both terrestrial and aquatic (marine and freshwater) ecosystems. Genomic analyses reveal a remarkable potential capacity to transform recalcitrant detrital material, particularly lignin-derived compounds, suggesting close linkages between the terrestrial and aquatic realms (Ghai et al., 2014). Their correlation with high FLU and low FAN values may indicate that these organisms are transported from freshwater to coastal ecosystems. Likewise, the Sphingobacteria that presented a significant IndVal in samples of High FLU and Low FAN categories are capable of degrading polymeric matter (Bergauer et al., 2018). Within the eukaryotes, our results indicate that abundances of an OTU attributed to the dinoflagellate Gymnodinium litoralis were positively correlated with concentrations of nitrate, silicate and phosphate. This species is known to produce recurrent near-shore high-biomass blooms in L'Estartit (Reñé et al., 2011), an area shown to have riverine influence and high availability of these inorganic nutrients (Tables 1 and S1). At broad taxonomic levels, Basal Fungi (Ophisthokonta) from nanoplankton were correlated with nitrate, silicate and phosphate. This lineage comprises a diverse group of heterotrophic, saprophytic and parasitic organisms, including the Chytridiomycota that contains many parasites of phytoplankton (Frenken et al., 2017, Grossart et al., 2019). The fact that they show positive correlations with inorganic nutrients could reflect their coupling with the higher abundances of potential hosts, like dinoflagellates. Likewise, other eukaryotic taxa exhibit significant IndVal scores confirming the potential to unveil indicators through 
the 'de novo approach'. Among these, the Chlorodendrophyceae (Archaeplastida) were indicator for samples subjected to low FAN and high FLU impacts. This group of prasinophytes (green algae) can be abundant in certain Mediterranean coastal stations (Tragin and Vaulot, 2018). Given their IndVal score in stations linked to a gradient of freshwater content as well as nitrate and silicate concentrations, their presence could be related to natural continental influences of fluvial origin. The uncultured marine stramenopiles MAST-3 and MAST-4 also displayed significant IndVal scores. These clades represent heterotrophic small protists that appear as common members in molecular surveys of marine picoplankton (Massana et al., 2004). Noteworthy, these taxa were indicative of water under low FLU impact (that is low freshwater, nitrate and silicate content). While certain clades of MAST have shown preference for brackish or freshwater environments, MAST-3 and MAST-4 have a clear preference for marine waters (Massana et al., 2014).

Besides indicator species or taxa, the potential of using the ratio between different groups of microorganisms as an alternative indicator of environmental status has been proposed (Garrido et al., 2014). In fact, in our previous survey we concluded that some bacterial indices, i.e. the ratio of Alphaproteobacteria / Gammaproteobacteria, Alteromonas / SAR11 and Alteromonas + Oceanospirillales / SAR11 could potentially become new tools in marine monitoring (Ferrera et al., 2016). Despite the promising results found in that proof-of-concept study, here we found that when comparing a range of conditions and accounting for certain temporal variation, these indices lost significance. Contrarily, the Actinobacteria / Rickettsiales ratio appeared to be correlated with the FLU index, and could potentially reflect continental pressures, particularly associated to areas of riverine influence (i.e., Alfacs and L'Estartit). On the other hand, no ratios with indicator potential were found within the small eukaryotes (up to $20 \mu \mathrm{m}$ ) although previous studies have claimed the potential of protists as indicators (see Pawlowski et al., 2018). This lack of consistency highlights the difficulty of finding operational indicators that can be widely used. 
Metabarcoding of environmental DNA provides a cost efficient approach for biodiversity monitoring and overcome many of the problems associated with traditional monitoring, offering the possibility to explore the use of microorganisms as bioindicators. In fact, its application has resulted in promising results in areas subjected to acute contamination but also along eutrophication gradients, particularly in sediments (Pawlowski et al., 2014; Aylagas et al., 2017; Stoeck et al., 2018). Although potential bioindicators were also unveiled in our study, the results are not as striking as those recently published by others. The structure and composition of the studied planktonic communities changed only slightly in areas of riverine influence and the shifts were even more negligible among sites under contrasting degrees of urban influence, represented by elevated values of nitrite and ammonia. A possible explanation for the differences in our results and those by other authors is the range of environmental pressures evaluated. Even though our study covers contrasting locations in terms of continental pressures, from hardly populated sites to the large city of Barcelona, the evaluated pressures here may have been more restrained. The study of Pearman et al. (2018) compared nearly pristine sites to areas impacted by a wastewater treatment plant effluent or the pressure from container ships calling the port of Jeddah, Saudi Arabia, and were able to detect taxa associated to sewage or fecal matter. Likewise, the microgAMBI (Aylagas et al., 2017) index was developed for the evaluation of anthropogenic impacts occurring in sediments subjected to a wide range of human pressures derived from industrial activities such as the presence of metals and chemical pollutants (PCB among others). Our study, moreover, covers from nearshore coastal sites to offshore stations and, even though we limited our study to end of spring and summer, we observed certain spatial and temporal variability in the FLU and FAN index values in each location (see Figures 2 and S4), supporting the known difficulties of setting ecological status boundaries in areas subjected to moderate degrees of impacts. It is possible that the natural spatial and seasonal variability (succession of continually changing communities) of the studied area may be constraining the potential of pico- and nanoplankton as indicators. A good biodiversity indicator should be able to distinguish the anthropogenic impact from natural 
variability (Borja et al., 2012). Microbial communities are known to display natural seasonality (Furhman et al., 2015; Auladell et al., 2019; Giner et al., 2019) which may challenge using these assemblages in environmental assessments unless baseline conditions are well known. In fact, community composition cannot be used as a quality indicator in an absolute sense but only in relation with known environmental conditions, and thus, previous information on the natural spatial and temporal variability of an area is necessary to establish a baseline of knowledge that allows to discriminate the natural from the human-derived variability. Yet, an operational indicator by definition must be implemented in a simple, fast and cheap manner. Requiring large efforts to establish a knowledge baseline for an indicator compromises its usefulness, which could be the case for pico- and nanoplankton, at least based in our results. Further yet, a recent study conducted in the Bay of Pozzuoli (Gulf of Naples, Mediterranean Sea) found that phytoplankton and prokaryotes showed a limited response to anthropogenic pressures and suggest that planktonic animals could in fact be better sentinels of impact (Margiotta et al., 2020).

Traditionally, with the exception of fecal indicators, microbes have not been used as indicators due to the difficulties in the taxonomic identification of environmental microorganisms. Nowadays, the use of sequencing technologies overcomes these limitations and allow to assess microbial community patterns in coastal regions in a faster and cheaper manner. In that sense, microbes have been proposed as indicators of marine environmental quality because they are known to react quickly to environmental changes, which makes them sensitive to disturbances. At the same time, however, communities have a large resilience and they are able to recover fast if the pressure is not permanent. As a result, in highly dynamic environments such as the pelagic realm, the small organisms of the plankton compartment may bear short-term memory of impact events and be poor indicators of environmental status, at least in areas of moderate impact. We thus conclude that in spite of the usefulness of environmental genomic-based approaches for biodiversity monitoring, translating pico- 
and nanoplankton diversity into fast and simple ecological indicators is challenging, in part due to the complexity and dynamics of these pelagic communities. Increasing our knowledge on plankton species responses to the natural environmental could however strengthen their potential as ecological indicators.

\section{Acknowledgments}

This work is an outcome of the DEVOTES (Development of innovative tools for understanding marine biodiversity and assessing GEnS) project, funded by the European Union (grant agreement $\mathrm{n}^{\circ}$ 308392), and the Spanish grant GRADIENTS (Fine-scale structure of cross-shore gradients along the Mediterranean coast, CTM201239479-C02). We thank all the people involved in running the Blanes Bay Microbial Observatory and the PUDEM Coastal Ocean Observatory (http.//coo.icm.csic.es/) for making the sampling possible and providing ancillary data. The Marine Bioinformatics Platform at ICM-CSIC (MARBITS; https://marbits.icm.csic.e) and particularly Dr. Ramiro Logares provided help with computing analyses. We also thank Elisabet Alacid, Silvia Anglès, Gotzon Basterretxea, Eva Flo, Antoni Jordi, Nagore Sampedro and Marta Turon for help with sampling and basic analyses, Vanessa Balagué for help extracting DNA and Natalia Timoneda for help with sequence submission to ENA.

\section{Author statement}

Isabel Ferrera: Conceptualization, Methodology, Investigation, Validation, Writing original draft, Reviewing, Editing; Albert Reñé: Conceptualization, Methodology, Investigation, Reviewing, Editing; David Funosas: Software, Analysis, Writing; Jordi

Camp: Conceptualization, Resources, Reviewing; Ramon Massana: Resources, Reviewing; Josep M Gasol: Resources, Reviewing; Esther Garcés: Conceptualization, Resources, Reviewing, Editing

\section{References}

Acinas, S.G., Antón, J., Rodríguez-Valera, F., 1999. Diversity of free-living and attached bacteria in offshore western Mediterranean waters as depicted by analysis of genes 
encoding 16S rRNA. Appl. Environ. Microbiol. 65, 514-522.

https://doi.org/10.1128/aem.65.2.514-522.1999

Apprill, A, McNally, S., Parsons, R., Weber, L., 2015. Minor revision to V4 region SSU rRNA 806R gene primer greatly increases detection of SAR11 bacterioplankton. Aquat. Microb. Ecol. 75, 129-137. https://doi.org/10.3354/ame01753

Arin, L., Guillén, J., Segura-Noguera, M., Estrada, M., 2013. Open sea hydrographic forcing of nutrient and phytoplankton dynamics in a Mediterranean coastal ecosystem. Estuar. Coast. Shelf Sci. 133, 116-128. https://doi.org/10.1016/j.ecss.2013.08.018

Auladell, A., Sánchez, P., Sánchez, O., Gasol, J.M., Ferrera, I., 2019. Long-term seasonal and interannual variability of marine aerobic anoxygenic photoheterotrophic bacteria, ISME Journal 13(8), 1975-1987. https://doi.org/10.1038/s41396-019-0401-4

Aylagas, E., Borja, Á., Irigoien, X., Rodríguez-Ezpeleta, N., 2016. Benchmarking DNA Metabarcoding for Biodiversity-Based Monitoring and Assessment. Front. Mar. Sci. 3, 1-12. https://doi.org/10.3389/fmars.2016.00096

Aylagas, E., Borja, Á., Tangherlini, M., Dell'Anno, A., Corinaldesi, C., Michell, C.T., Irigoien, X., Danovaro, R., Rodríguez-Ezpeleta, N., 2017. A bacterial communitybased index to assess the ecological status of estuarine and coastal environments. Mar. Pollut. Bull. 114, 679-688. https://doi.org/10.1016/i.marpolbul.2016.10.050

Basterretxea, G., Torres-Serra, F.J., Alacid, E., Anglès, S., Camp, J., Ferrera, I., Flo, E., Font-Muñoz, J.S., Jordi, A., Reñé, A., Salgado-Hernanz, P.M., Sampedro, N., Garcés, E., 2018. Cross-shore environmental gradients in the Western Mediterranean coast and their influence on nearshore phytoplankton communities. Front. Mar. Sci. 5, 78. https://doi.org/10.3389/fmars.2018.00078

Bergauer, K., Fernandez-Guerra, A., Garcia, J.A.L., Sprenger, R.R., Stepanauskas, R., Pachiadaki, M.G., Jensen, O.N., Herndl, G.J., 2018. Organic matter processing by microbial communities throughout the Atlantic water column as revealed by metaproteomics. Proc. Natl. Acad. Sci. U. S. A. 115, E400-E408. https://doi.org/10.1073/pnas.1708779115

Birk, S., Bonne, W., Borja, A., Brucet, S., Courrat, A., Poikane, S., Solimini, A., Van De Bund, W., Zampoukas, N., Hering, D., 2012. Three hundred ways to assess Europe's surface waters: an almost complete overview of biological methods to implement the Water Framework Directive. Ecol. Indic. 18, 31-41. https://doi.org/10.1016/j.scitotenv.2019.02.251

Borja, Á., Dauer, D.M., Grémare, A., 2012. The importance of setting targets and reference conditions in assessing marine ecosystem quality. Ecol. Indic. 12, 1-7. https://doi.org/10.1016/j.ecolind.2011.06.018

Borja, A., Elliott, M., Carstensen, J., Heiskanen, A.-S., van de Bund, W., 2010. Marine management-towards an integrated implementation of the European Marine Strategy Framework and the Water Framework Directives. Mar. Pollut. Bull. 60, 2175-2186. https://doi.org/10.1016/j.marpolbul.2010.09.026

Camp, J., Flo, E., Vila, M., Arin, L., Reñé, A., Sampedro, N., Manzanera, M., Garcés, E., 2006. Pros and Cons of Biological Quality Element Phytoplankton as a WaterQuality Indicator in the NW Mediterranean Sea, in: Handbook of Environmental Chemistry. pp. 1-12. https://doi.org/10.1007/698

Caruso, G., La Ferla, R., Azzaro, M., Zoppini, A., Marino, G., Petochi, T., Corinaldesi, C., Leonardi, M., Zaccone, R., Fonda Umani, S., Caroppo, C., Monticelli, L.S., Azzaro, F., Decembrini, F., Maimone, G., Cavallo, R.A., Stabili, L., Hristova Todorova, N., K. Karamfilov, V., Rastelli, E., Cappello, S., Acquaviva, M.I., Narracci, M., De Angelis, R., Del Negro, P., Latini, M., Danovaro, R., 2015. Microbial assemblages for environmental quality assessment: Knowledge, gaps and usefulness in the European Marine Strategy Framework Directive. Crit. Rev. Microbiol. 7828, 1-22. https://doi.org/10.3109/1040841X.2015.1087380

Cavicchioli, R., Ripple, W.J., Timmis, K.N., Azam, F., Bakken, L.R., Baylis, M., Behrenfeld, M.J., Boetius, A., Boyd, P.W., Classen, A.T., Crowther, T.W., 
Danovaro, R., Foreman, C.M., Huisman, J., Hutchins, D.A., Jansson, J.K., Karl, D.M., Koskella, B., Mark Welch, D.B., Martiny, J.B.H., Moran, M.A., Orphan, V.J., Reay, D.S., Remais, J. V., Rich, V.I., Singh, B.K., Stein, L.Y., Stewart, F.J.,

Sullivan, M.B., van Oppen, M.J.H., Weaver, S.C., Webb, E.A., Webster, N.S., 2019. Scientists' warning to humanity: microorganisms and climate change. Nat. Rev. Microbiol. 17, 569-586. https://doi.org/10.1038/s41579-019-0222-5

Chao, A., Lee, S.-M., 1992. Estimating the Number of Classes via Sample Coverage. J. Am. Stat. Assoc. 87, 210-217. https://doi.org/10.1080/01621459.1992.10475194

Cordier, T., Sáez, L.A., Apotheloz-Perret-Gentil, L., Aylagas, E., Bohan, D.A., Bouchez, A., Chariton, A., Creer, S., Fruhe, L., Keck, F., 2020. Ecosystems Monitoring Powered by Environmental Genomics: A Review of Current Strategies with An Implementation Roadmap. https://doi.org/10.1111/mec.15472

Cúcio, C., Engelen, A.H., Costa, R., Muyzer, G., 2016. Rhizosphere Microbiomes of European + Seagrasses Are Selected by the Plant, But Are Not Species Specific.

Front. Microbiol. 7, 1-15. https://doi.org/10.3389/fmicb.2016.00440

Danovaro, R., Carugati, L., Berzano, M., Cahill, A.E., Carvalho, S., Chenuil, A., Corinaldesi, C., Cristina, S., David, R., Dell'Anno, A., Dzhembekova, N., Garcés, E., Gasol, J.M., Goela, P., Féral, J.-P., Ferrera, I., Forster, R.M., Kurekin, A.A., Rastelli, E., Marinova, V., Miller, P.I., Moncheva, S., Newton, A., Pearman, J.K., Pitois, S.G., Reñé, A., Rodríguez-Ezpeleta, N., Saggiomo, V., Simis, S.G.H., Stefanova, K., Wilson, C., Martire, M.L., Greco, S., Cochrane, S.K.J., Mangoni, O., Borja, A., 2016. Implementing and innovating marine monitoring approaches for assessing marine environmental status. Front. Mar. Sci. 3. https://doi.org/10.3389/fmars.2016.00213

Davidson, A.D., Boyer, A.G., Kim, H., Pompa-Mansilla, S., Hamilton, M.J., Costa, D.P., Ceballos, G., Brown, J.H., 2012. Drivers and hotspots of extinction risk in marine mammals. Proc. Natl. Acad. Sci. 109, 3395-3400. https://doi.org/10.1073/pnas.1121469109

Directive, Marine Strategy Framework. "Directive 2008/56/EC of the European Parliament and of the Council of 17 June 2008 establishing a framework for community action in the field of marine environmental policy." Official Journal of the European Union L 164 (2008): 19-40.

Directive, Water Framework. "Directive 2000/60/EC of the European Parliament and of the Council of 23 October 2000 establishing a framework for Community action in the field of water policy." Official journal of the European communities 22.12 (2000).

Dufrêne, M., Legendre, P., 1997. Species assemblages and indicator species: The need for a flexible asymmetrical approach. Ecol. Monogr. 67, 345-366. https://doi.org/10.1890/0012-9615(1997)067[0345:SAAIST]2.0.CO;2

Fernández Ruiz, L., 2012. Las aguas subterráneas en la planificación hidrogeológica. Instituto Geológico y Minero de España. Madrid, 481.

Ferrera, I., Giner, C.R., Reñé, A., Camp, J., Massana, R., Gasol, J.M., Garcés, E., 2016. Evaluation of Alternative High-Throughput Sequencing Methodologies for the Monitoring of Marine Picoplanktonic Biodiversity Based on rRNA Gene Amplicons. Front. Mar. Sci. 3, 147. https://doi.org/10.3389/fmars.2016.00147

Flo Arcas, E., 2017. Opening the black box of coastal inshore waters in the NW Mediterranean Sea: environmental quality tools and assessment. Doctoral Thesis. http://hdl.handle.net/10261/160058

Flo, E., Garcés, E., Camp, J., 2019. Land Uses Simplified Index ( LUSI ): Determining Land Pressures and Their Link With Coastal Eutrophication. Front. Mar. Sci. 6, 118. https://doi.org/10.3389/fmars.2019.00018

Flo, E., Garcés, E., Manzanera, M., Camp, J., 2011. Coastal inshore waters in the NW Mediterranean: Physicochemical and biological characterization and management implications. Estuar. Coast. Shelf Sci. 93, 279-289. https://doi.org/10.1016/i.ecss.2011.04.002

Frenken, T., Alacid, E., Berger, S.A., Bourne, E.C., Gerphagnon, M., Grossart, H.P., Gsell, A.S., Ibelings, B.W., Kagami, M., Küpper, F.C., Letcher, P.M., Loyau, A., 
Miki, T., Nejstgaard, J.C., Rasconi, S., Reñé, A., Rohrlack, T., Rojas-Jimenez, K., Schmeller, D.S., Scholz, B., Seto, K., Sime-Ngando, T., Sukenik, A., Van de Waal, D.B., Van den Wyngaert, S., Van Donk, E., Wolinska, J., Wurzbacher, C., Agha, R., 2017. Integrating chytrid fungal parasites into plankton ecology: research gaps and needs. Environ. Microbiol. 19, 3802-3822. https://doi.org/10.1111/1462-2920.13827

Fuhrman, J.A., Cram, J.A., Needham, D.M., 2015. Marine microbial community dynamics and their ecological interpretation. Nat. Rev. Microbiol. 13, 133-146. https://doi.org/10.1038/nrmicro3417

Galand, P.E., Lucas, S., Fagervold, S.K., Peru, E., Pruski, A.M., Vétion, G., Dupuy, C., Guizien, K., 2016. Disturbance increases microbial community diversity and production in marine sediments. Front. Microbiol. 7, 1-11. https://doi.org/10.3389/fmicb.2016.01950

Gall, S.C., Thompson, R.C., 2015. The impact of debris on marine life. Mar. Pollut. Bull. 92, 170-179. https://doi.org/10.1016/i.marpolbul.2014.12.041

Garrido, L., Sánchez, O., Ferrera, I., Tomàs, N., Mas, J., 2014. Dynamics of microbial diversity profiles in waters of different qualities. Approximation to an ecological quality indicator. Sci. Total Environ. 468-469, 1154-1161. https://doi.org/10.1016/j.scitotenv.2013.08.065

Gasol, J.M., Cardelús, C., Morán, X.A.G., Balagué, V., Forn, I., Marrasé, C., Massana, R., Pedrós-alió, C., Sala, M.M., Simó, R., Vaqué, D., Estrada, M., 2016. Seasonal patterns in phytoplankton photosynthetic parameters and primary production at a coastal NW Mediterranean site. Sci. Mar. 80S1, 63-77. https://doi.org/10.3989/scimar.04480.06E

Gasol, J.M., Kirchman, D.L., 2018. Microbial ecology of the oceans. John Wiley \& Sons.

Ghai, R., Mizuno, C., Picazo, A., Camacho, A., Rodriguez-Valera, F., 2014. Key roles for freshwater Actinobacteria revealed by deep metagenomic sequencing. Mol. Ecol. 23(24), 6073-6090. https://doi.org/10.1111/mec.12985

Giner, C.R., Balagué, V., Krabberød, A.K., Ferrera, I., Reñé, A., Garcés, E., Gasol, J.M., Logares, R., Massana, R., 2019. Quantifying long- term recurrence in planktonic microbial eukaryotes. Mol. Ecol. 28, 923-935. https://doi.org/10.1111/mec.14929

Grasshoff, K., Kremling, K., Ehrhardt, M., 2009. Methods of seawater analysis. John Wiley \& Sons.

Grossart, H.P., Van den Wyngaert, S., Kagami, M., Wurzbacher, C., Cunliffe, M., RojasJimenez, K., 2019. Fungi in aquatic ecosystems. Nat. Rev. Microbiol. 17, 339-354. https://doi.org/10.1038/s41579-019-0175-8

Halpern, B.S., Selkoe, K.A., Micheli, F., Kappel, C. V., 2007. Evaluating and ranking the vulnerability of global marine ecosystems to anthropogenic threats. Conserv. Biol. 21, 1301-1315. https://doi.org/10.1111/j.1523-1739.2007.00752.x

Halpern, B.S., Walbridge, S., Selkoe, K.A., Kappel, C. V., Micheli, F., D’Agrosa, C., Bruno, J.F., Casey, K.S., Ebert, C., Fox, H.E., Fujita, R., Heinemann, D., Lenihan, H.S., Madin, E.M.P., Perry, M.T., Selig, E.R., Spalding, M., Steneck, R., Watson, R., 2008. A global map of human impact on Marine Ecosystems. Science 319, 948953. https://doi.org/10.1126/science.1149345

Herlemann, D.P., Labrenz, M., Jürgens, K., Bertilsson, S., Waniek, J.J., Andersson, A.F., 2011. Transitions in bacterial communities along the $2000 \mathrm{~km}$ salinity gradient of the Baltic Sea. ISME J. 5, 1571-9. https://doi.org/10.1038/ismej.2011.41

Hoegh-Guldberg, O., Bruno, J.F., 2010. The impact of climate change on the world's marine ecosystems. Science 328, 1523-1528.

https://doi.org/10.1126/science. 1189930

Holm, S., 1979. A Simple Sequentially Rejective Multiple Test Procedure. Scand. J. Stat. 6, 65-70. https://www.jstor.org/stable/4615733 
Hummel, H., Frost, M., Juanes, J.A., Kochmann, J., Bolde, C.F.C.P., Aneiros, F., Vandenbosch, F., Franco, J.N., Echavarri, B., Guinda, X., Puente, A., Fernández, C., Galván, C., Merino, M., Ramos, E., Fernández, P., Pitacco, V., Alberte, M., Wojcik, D., Grabowska, M., Jahnke, M., Crocetta, F., Carugati, L., Scorrano, S., Fraschetti, S., García, P.P., Sanabria Fernández, J.A., Poromov, A., lurchenko, A., Isachenko, A., Chava, A., Pavloudi, C., Bordeyne, F., Andersen, S.F., Eronat, E.G.T., Cakmak, T., Louizidou, P., Rico, J., Ruci, S., Corta Diego, D., Mendez, S., Rousou, M., De Clippele, L., Eriksson, A., Van Zanten, W., Diamant, A., De Matos, V.K.F., 2015. A comparison of the degree of implementation of marine biodiversity indicators by European countries in relation to the Marine Strategy Framework Directive (MSFD). J. Mar. Biol. Assoc. United Kingdom 95, 1519-1531. https://doi.org/10.1017/S0025315415000235

Liquete, C., Piroddi, C., Drakou, E.G., Gurney, L., Katsanevakis, S., Charef, A., Egoh, B., 2013. Current status and future prospects for the assessment of marine and coastal ecosystem services: a systematic review. PLoS One 8. https://doi.org/10.1371/journal.pone.0067737

Logares, R., 2017. Workflow for Analysing MiSeq Amplicons based on Uparse v1.5. Zenodo10 5281. https://doi.org/10.5281/zenodo.259579

Lumbreras, A., Marques, J.T., Belo, A.F., Cristo, M., Fernandes, M., Galioto, D., Machado, M., Mira, A., Sá-Sousa, P., Silva, R., 2016. Assessing the conservation status of Mediterranean temporary ponds using biodiversity: a new tool for practitioners. Hydrobiologia 782, 187-199. https://doi.org/10.1016/j.marpolbul.2016.10.050

Magurran, A.E., 1988. Ecological diversity and its measurements. Princet. Univ. Press. New Jersey. 177pp.

Margiotta, F., Balestra, C., Buondonno, A., Casotti, R., D’Ambra, I., Di Capua, I., Gallia, R., Mazzocchi, M.G., Merquiol, L., Pepi, M., Percopo, I., Saggiomo, M., Sarno, D., Zingone, A, 2020. Do plankton reflect the environmental quality status? The case of a post-industrial Mediterranean Bay. Mar. Environ. Res. 104980. https://doi.org/10.1016/j.marenvres.2020.104980

Massana, R., Castresana, J., Balagué, V., Guillou, L., Romari, K., Groisillier, A., Valentin, K., Pedrós-Alió, C., 2004. Phylogenetic and ecological analysis of novel marine stramenopiles. Appl. Environ. Microbiol. 70, 3528-3534. https://doi.org/10.1128/AEM.70.6.3528-3534.2004

Massana, R., Del Campo, J., Sieracki, M.E., Audic, S., Logares, R., Campo, J., Sieracki, M.E., 2014. Exploring the uncultured microeukaryote majority in the oceans: reevaluation of ribogroups within stramenopiles. ISME J. 8, 854-66. https://doi.org/10.1038/ismej.2013.204

Massana, R., Murray, a E., Preston, C.M., DeLong, E.F., 1997. Vertical distribution and phylogenetic characterization of marine planktonic Archaea in the Santa Barbara Channel. Appl. Environ. Microbiol. 63, 50-56. https://doi.org/10.1128/aem.63.1.50$\underline{56.1997}$

Nikolenko, S.I., Korobeynikov, A.I., Alekseyev, M.A., 2013. BayesHammer: Bayesian Clustering for Error Correction in Single-Cell Sequencing. BMC Genomics 14. https://doi.org/10.1186/1471-2164-14-S1-S7

Nogales, B., Lanfranconi, M.P., Piña-Villalonga, J.M., Bosch, R., 2011. Anthropogenic perturbations in marine microbial communities. FEMS Microbiol. Rev. 35, 275-298. https://doi.org/10.1111/j.1574-6976.2010.00248.x

Nurk, S., Bankevich, A., Antipov, D., Gurevich, A., Korobeynikov, A., Lapidus, A., Prjibelsky, A., Pyshkin, A., Sirotkin, A., Sirotkin, Y., Stepanauskas, R., McLean, J., Lasken, R., Clingenpeel, S.R., Woyke, T., Tesler, G., Alekseyev, M.A., Pevzner, $P . A ., 2013$. Assembling genomes and mini-metagenomes from highly chimeric reads, in: Lecture Notes in Computer Science (Including Subseries Lecture Notes in Artificial Intelligence and Lecture Notes in Bioinformatics). pp. 158-170.

https://doi.org/10.1007/978-3-642-37195-0_13 
Obiol, A., Giner, C.R., Sánchez, P., Duarte, C.M., Acinas, S.G., Massana, R., 2020. A metagenomic assessment of microbial eukaryotic diversity in the global ocean. Mol. Ecol. Resour. 1-14. https://doi.org/10.1111/1755-0998.13147

Pawlowski, J., Esling, P., Lejzerowicz, F., Cedhagen, T., Wilding, T.A., 2014. Environmental monitoring through protist next-generation sequencing metabarcoding: Assessing the impact of fish farming on benthic foraminifera communities. Mol. Ecol. Resour. 14, 1129-1140. https://doi.org/10.1111/17550998.12261

Pawlowski, J., Kelly-Quinn, M., Altermatt, F., Apothéloz-Perret-Gentil, L., Beja, P., Boggero, A., Borja, A., Bouchez, A., Cordier, T., Domaizon, I., Feio, M.J., Filipe, A.F., Fornaroli, R., Graf, W., Herder, J., van der Hoorn, B., Iwan Jones, J., SagovaMareckova, M., Moritz, C., Barquín, J., Piggott, J.J., Pinna, M., Rimet, F., Rinkevich, B., Sousa-Santos, C., Specchia, V., Trobajo, R., Vasselon, V., Vitecek, S., Zimmerman, J., Weigand, A., Leese, F., Kahlert, M., 2018. The future of biotic indices in the ecogenomic era: Integrating (e)DNA metabarcoding in biological assessment of aquatic ecosystems. Sci. Total Environ. 637-638, 1295-1310. https://doi.org/10.1016/j.scitotenv.2018.05.002

Pearman, J.K., Afandi, F., Hong, P., Carvalho, S., 2018. Plankton community assessment in antrophogenic-impacted oligotrophic coastal regions. Environ. Sci. Pollut. Res. 25, 31017-31030. https://doi.org/10.1007/s11356-018-3072-1

Polz, M.F., Cavanaugh, C.M., 1998. Bias in template-to-product ratios in multitemplate PCR. Appl. Environ. Microbiol. 64, 3724-3730.

https://aem.asm.org/content/64/10/3724

R Development Core Team. 2015. https://www.r-project.org/

Reñé, A., Satta, C.T., Garcés, E., Massana, R., Zapata, M., Anglès, S., Camp, J., 2011. Gymnodinium litoralis sp. nov.(Dinophyceae), a newly identified bloom-forming dinoflagellate from the NW Mediterranean Sea. Harmful Algae 12, 11-25. https://doi.org/10.1016/..hal.2011.08.008

Rodellas, V., Garcia-Orellana, J., Tovar-Sánchez, A., Basterretxea, G., López-Garcia, J.M., Sánchez-Quiles, D., Garcia-Solsona, E., Masqué, P., 2014. Submarine groundwater discharge as a source of nutrients and trace metals in a Mediterranean bay (Palma Beach, Balearic Islands). Mar. Chem. 160, 56-66. https://doi.org/10.1016/J.MARCHEM.2014.01.007

Sokal, R.R., Rohlf, F.J., 1995. The arcsine transformation, in: Biometry. WH Freeman New York, New York.

Stoeck, T., Bass, D., Nebel, M., Christen, R., Jones, M.D.M., Breiner, H.W., Richards, T.A., 2010. Multiple marker parallel tag environmental DNA sequencing reveals a highly complex eukaryotic community in marine anoxic water. Mol. Ecol. 19, 21-31. https://doi.org/10.1111/j.1365-294X.2009.04480.x

Stoeck, T., Frühe, L., Forster, D., Cordier, T., Martins, C.I.M., Pawlowski, J., 2018. Environmental DNA metabarcoding of benthic bacterial communities indicates the benthic footprint of salmon aquaculture. Mar. Pollut. Bull. 127, 139-149. https://doi.org/10.1016/j.marpolbul.2017.11.065

Tovar-Sánchez, A., Basterretxea, G., Rodellas, V., Sánchez-Quiles, D., García-Orellana, J., Masqué, P., et al., 2014. Contribution of groundwater discharge to the coastal dissolved nutrients and trace metal concentrations in Majorca Island: karstic vs detrital systems. Environ. Sci. Technol. 48, 11819-11827. https://doi.org/10.1021/es502958t

Tragin, M., Vaulot, D., 2018. Green microalgae in marine coastal waters: The Ocean Sampling Day (OSD) dataset. Sci. Rep. 8, 1-12. https://doi.org/10.1038/s41598$\underline{018-32338-w}$ 
Table 1. Values (average \pm standard deviation, minimum to maximum) of the FLU and FAN impact indices as well as of the measured environmental variables in each sampling area.

\begin{tabular}{|c|c|c|c|c|c|c|c|c|c|c|c|}
\hline Site & $\begin{array}{l}\text { Number } \\
\text { of } \\
\text { samples }\end{array}$ & $\begin{array}{c}\text { Temperature } \\
\left({ }^{\circ} \mathrm{C}\right)\end{array}$ & $\begin{array}{l}\text { Salinity } \\
\text { (psu) }\end{array}$ & $\begin{array}{l}\mathrm{PO}_{4}{ }^{3+} \\
(\mu \mathrm{M})\end{array}$ & $\begin{array}{l}\mathrm{NH}_{4}^{+} \\
(\mu \mathrm{M})\end{array}$ & $\begin{array}{l}\mathrm{NO}_{2}^{-} \\
(\mu \mathrm{M})\end{array}$ & $\begin{array}{l}\mathrm{NO}_{3}^{-} \\
(\mu \mathrm{M})\end{array}$ & $\underset{(\mu \mathrm{M})}{\mathrm{Si}}$ & $\begin{array}{c}\text { Chl a } \\
\text { concentration } \\
\left(\mu \mathrm{g} \cdot \mathrm{L}^{-1}\right)\end{array}$ & FLU & FAN \\
\hline Alfacs & 4 & $\begin{array}{c}26.5 \pm 0.4 \\
(26.0 \text { to } 26.8)\end{array}$ & $\begin{array}{c}35.85 \pm 0.42 \\
(35.30 \text { to } \\
36.3)\end{array}$ & $\begin{array}{c}0.16 \pm 0.02 \\
(0.13 \text { to } 0.18)\end{array}$ & $\begin{array}{c}0.84 \pm 0.72 \\
(0.04 \text { to } \\
1.67)\end{array}$ & $\begin{array}{c}0.12 \pm 0.04 \\
(0.09 \text { to } 0.18)\end{array}$ & $\begin{array}{c}0.60 \pm 0.40 \\
(0.33 \text { to } 1.19)\end{array}$ & $\begin{array}{c}8.08 \pm 4.37 \\
(2.65 \text { to } \\
11.88)\end{array}$ & $\begin{array}{c}1.96 \pm 0.45 \\
(1.52 \text { to } 2.39)\end{array}$ & $\begin{array}{c}60.1 \pm 14.6 \\
(42.9 \text { to } 77.2)\end{array}$ & $\begin{array}{c}-22.2 \pm 6.0 \\
(-29.5 \text { to }-15.4)\end{array}$ \\
\hline Barcelona & 23 & $\begin{array}{c}23.1 \pm 1.8 \\
(20.3 \text { to } 26.0)\end{array}$ & $\begin{array}{c}37.79 \pm 0.19 \\
(37.04 \text { to } \\
38.01)\end{array}$ & $\begin{array}{c}0.12 \pm 0.08 \\
(0.02 \text { to } 0.35)\end{array}$ & $\begin{array}{c}1.15 \pm 1.12 \\
(0.12 \text { to } \\
4.01)\end{array}$ & $\begin{array}{c}0.21 \pm 0.21 \\
(0.00 \text { to } 0.98)\end{array}$ & $\begin{array}{c}0.73 \pm 0.84 \\
(0.04 \text { to } 3.91)\end{array}$ & $\begin{array}{c}1.16 \pm 2.01 \\
(0.10 \text { to } 9.17)\end{array}$ & $\begin{array}{l}0.79 \pm 0.49 \\
0.15 \text { to } 1.82\end{array}$ & $\begin{array}{c}7.7 \pm 4.4 \\
(2.4 \text { to } 24.2)\end{array}$ & $\begin{array}{c}-1.9 \pm 2.8 \\
(-9.8 \text { to } 4.1)\end{array}$ \\
\hline Blanes & 35 & $\begin{array}{c}22.5 \pm 2.5 \\
(16.5 \text { to } 26.2)\end{array}$ & $\begin{array}{c}37.59 \pm 0.71 \\
(35.08 \text { to } \\
38.17)\end{array}$ & $\begin{array}{c}0.10 \pm 0.06 \\
(0.02 \text { to } 0.23)\end{array}$ & $\begin{array}{l}1.06 \pm 0.83 \\
\text { (0.1 to } 3.48)\end{array}$ & $\begin{array}{c}0.13 \pm 0.16 \\
(0.01 \text { to } 0.87)\end{array}$ & $\begin{array}{c}0.34 \pm 0.28 \\
(0.03 \text { to } 1.38)\end{array}$ & $\begin{array}{c}0.87 \pm 0.54 \\
(0.04 \text { to } 2.22)\end{array}$ & $\begin{array}{l}0.33 \pm 0.20 \\
0.02 \text { to } 0.86\end{array}$ & $\begin{array}{c}11.7 \pm 16.1 \\
(-0.85 \text { to } 69.4)\end{array}$ & $\begin{array}{c}-4.0 \pm 6.5 \\
(-27.1 \text { to } 3.1)\end{array}$ \\
\hline L'Estartit & 10 & $\begin{array}{c}21.4 \pm 0.2 \\
(20.9 \text { to } 21.7)\end{array}$ & $\begin{array}{c}36.62 \pm 0.79 \\
(35.14 \text { to } \\
37.47)\end{array}$ & $\begin{array}{c}0.41 \pm 0.40 \\
(0.11 \text { to } 1.23)\end{array}$ & $\begin{array}{c}0.23 \pm 0.20 \\
(0.03 \text { to } \\
0.62)\end{array}$ & $\begin{array}{c}0.25 \pm 0.23 \\
(0.07 \text { to } 0.79)\end{array}$ & $\begin{array}{c}7.90 \pm 10.30 \\
(0.18 \text { to } \\
31.27)\end{array}$ & $\begin{array}{c}15.15 \pm 17.09 \\
(1.36 \text { to } \\
52.96)\end{array}$ & $\begin{array}{l}1.29 \pm 1.05 \\
0.21 \text { to } 3.65\end{array}$ & $\begin{array}{c}56.9 \pm 44.7 \\
(15.5 \text { to } 144.4)\end{array}$ & $\begin{array}{c}-18.1 \pm 11.4 \\
(-38.6 \text { to }-6.8)\end{array}$ \\
\hline $\begin{array}{l}\text { L'Hospitalet } \\
\text { de l'Infant }\end{array}$ & 10 & $\begin{array}{c}24.6 \pm 0.3 \\
(24.1 \text { to } 25.1)\end{array}$ & $\begin{array}{c}36.65 \pm 0.42 \\
(35.53 \text { to } \\
37.14)\end{array}$ & $\begin{array}{c}0.13 \pm 0.02 \\
(0.11 \text { to } 0.17)\end{array}$ & $\begin{array}{c}0.24 \pm 0.18 \\
(0.02 \text { to } \\
0.57)\end{array}$ & $\begin{array}{c}0.12 \pm 0.02 \\
(0.08 \text { to } 0.15)\end{array}$ & $\begin{array}{c}0.88 \pm 0.78 \\
(0.32 \text { to } 2.82)\end{array}$ & $\begin{array}{c}0.81 \pm 0.70 \\
(0.32 \text { to } 2.14)\end{array}$ & $\begin{array}{l}1.01 \pm 0.39 \\
0.67 \text { to } 1.80\end{array}$ & $\begin{array}{c}34.0 \pm 10.8 \\
(22.0 \text { to } 62.4)\end{array}$ & $\begin{array}{c}-13.8 \pm 4.2 \\
(-25.0 \text { to }-9.5)\end{array}$ \\
\hline Palma & 11 & $\begin{array}{c}29.4 \pm 0.7 \\
(28.0 \text { to } 30.8)\end{array}$ & $\begin{array}{c}37.6 \pm 0.05 \\
(37.46 \text { to } \\
37.64)\end{array}$ & $\begin{array}{c}0.17 \pm 0.05 \\
(0.11 \text { to } 0.26)\end{array}$ & $\begin{array}{c}0.29 \pm 0.28 \\
(0.06 \text { to } \\
1.02)\end{array}$ & $\begin{array}{c}0.10 \pm 0.14 \\
(0.02 \text { to } 0.51)\end{array}$ & $\begin{array}{c}0.96 \pm 1.16 \\
(0.06 \text { to } 4.04)\end{array}$ & $\begin{array}{c}1.02 \pm 0.40 \\
(0.72 \text { to } 2.06)\end{array}$ & $\begin{array}{l}0.67 \pm 0.48 \\
0.29 \text { to } 1.77\end{array}$ & $\begin{array}{c}12.7 \pm 1.58 \\
(10.8 \text { to } 15.3)\end{array}$ & $\begin{array}{c}-5.1 \pm 0.4 \\
(-5.5 \text { to }-4.1)\end{array}$ \\
\hline
\end{tabular}


Table 2. Potential indicator taxonomic groups identified by significant IndVal for the various categories and the FLU and FAN impact indices that each sample falls into. Pico (picoplankton) corresponds to the $0.2-3 \mu \mathrm{m}$ fraction; nano (nanoplankton) corresponds to the $3-20 \mu \mathrm{m}$ fraction. Abundance (\%) indicates the mean relative abundance of that taxon in the corresponding fraction.

\begin{tabular}{|c|c|c|c|c|c|c|c|}
\hline Domain & $\begin{array}{c}\text { Size } \\
\text { Fractio } \\
\mathbf{n} \\
\end{array}$ & Taxonomic group & $\begin{array}{c}\text { Rel. } \\
\text { Abund. } \\
(\%)\end{array}$ & $\begin{array}{c}\text { Variabl } \\
\text { e }\end{array}$ & $\begin{array}{c}\text { Categor } \\
y\end{array}$ & $\underset{I}{\operatorname{IndVa}}$ & P-value \\
\hline \multirow[t]{9}{*}{$\begin{array}{c}\text { Prokaryote } \\
\mathrm{s}\end{array}$} & pico & Actinobacteria & 4.37 & FAN & Low & 0.59 & $3.0 e^{-04}$ \\
\hline & pico & Sphingobacteriia & 2.05 & FAN & Low & 0.48 & $5.0 e^{-04}$ \\
\hline & pico & Actinobacteria & 4.37 & FLU & High & 0.60 & $3.0 e^{-04}$ \\
\hline & pico & Sphingobacteriia & 2.05 & FLU & High & 0.49 & $3.0 e^{-04}$ \\
\hline & nano & Sphingobacteriia & 5.68 & FAN & Low & 0.53 & $3.0 e^{-04}$ \\
\hline & nano & Planctomycetes & 2.42 & FAN & Low & 0.46 & $1.5 e^{-03}$ \\
\hline & nano & Flavobacteriia & 15.05 & FLU & Medium & 0.41 & $2.4 e^{-02}$ \\
\hline & nano & Sphingobacteriia & 5.68 & FLU & High & 0.53 & $3.0 e^{-04}$ \\
\hline & nano & Planctomycetes & 2.42 & FLU & High & 0.44 & $1.4 e^{-02}$ \\
\hline \multirow[t]{6}{*}{ Eukaryotes } & pico & $\begin{array}{c}\text { Chlorodendrophycea } \\
\text { e (Archaeplastida) }\end{array}$ & 4.76 & FAN & Low & 0.73 & $5.8 e^{-03}$ \\
\hline & pico & $\begin{array}{c}\text { Chlorodendrophycea } \\
\text { e (Archaeplastida) }\end{array}$ & 4.76 & FLU & High & 0.68 & $3.4 e^{-02}$ \\
\hline & pico & Telonema (Hacrobia) & 0.67 & FLU & Low & 0.52 & $3.4 e^{-02}$ \\
\hline & pico & Cercozoa (Rhizaria) & 1.7 & FLU & Low & 0.55 & $1.9 e^{-03}$ \\
\hline & pico & $\begin{array}{c}\text { MAST_3 } \\
\text { (Stramenopiles) }\end{array}$ & 1.94 & FLU & Low & 0.51 & $1.2 \mathrm{e}^{-02}$ \\
\hline & pico & $\begin{array}{c}\text { MAST_4 } \\
\text { (Stramenopiles) }\end{array}$ & 0.77 & FLU & Low & 0.54 & $2.9 e^{-02}$ \\
\hline
\end{tabular}




\section{Figure Legends}

Figure 1. Map of the NW Mediterranean area showing the sampled areas (source: QGIS Geographic Information System, http://qgis.osgeo.org).

Figure 2. Box plots of the FLU and FAN impact indices for each sampling location. Letters shown in the boxes represent the results of a Tukey HSD test. Areas not connected by the same letter are significantly different $(p<0.05)$.

Figure 3. Box plots of prokaryotic richness (Chao1) and diversity (Shannon) indices depending on the categories of the FLU and FAN impact indices that each sample falls into (Low, Medium, High). Two plankton size fractions were analyzed separately (nano: nanoplankton; pico: picoplankton). No significant differences were found (ANOVA, $\mathrm{p}<0.05)$.

Figure 4. Box plots of eukaryotic richness (Chao1) and diversity (Shannon) indices depending on the categories of the FLU and FAN impact indices that each sample falls into (Low, Medium, High). Two plankton size fractions were analyzed separately (nano: nanoplankton; pico: picoplankton). ${ }^{*}$ Asterisks indicate that differences for that category and size fraction were significant (Tukey HSD test at $p<0.05$ ).

Figure 5. Bar plots showing the relative abundances of prokaryotic (left) and eukaryotic (right) taxa depending on the FLU and FAN impact index categories (Low, Medium or High). Two plankton size fractions were analyzed separately (nano: nanoplankton; pico: picoplankton).

Figure 6. Box plot showing the differences in the Actinobacteria / Rickettsiales ratio in the picoplankton fraction along the FLU and FAN index categories. 
A revised manuscript submitted to Marine Pollution Bulletin

\title{
Assessment of microbial plankton diversity as an ecological indicator in the NW Mediterranean coast
}

\author{
$\underline{\text { Isabel Ferrera }}{ }^{1,2^{*}}$, Albert Reñé $^{1}$, David Funosas ${ }^{1}$, Jordi Camp ${ }^{1}$, Ramon Massana ${ }^{1}$, Josep \\ M. Gasol ${ }^{1}$ \& Esther Garcés ${ }^{1 *}$ \\ ${ }^{1}$ Departament de Biologia Marina i Oceanografia, Institut de Ciències del Mar, CSIC, \\ Barcelona, Catalunya, Spain \\ ${ }^{2}$ Centro Oceanográfico de Málaga, Instituto Español de Oceanografía, Fuengirola, \\ Málaga, Spain
}

Running title: microbial plankton as an ecological indicator

${ }^{*}$ Correspondence: Isabel Ferrera isabel.ferrera@ieo.es

Centro Oceanográfico de Málaga, Puerto Pesquero s/n, 29640 Fuengirola, Málaga, Spain, tel. (+34) 952197 124, FAX (+34) 952581388 ;

^Esther Garcés: esther@icm.csic.es Institut de Ciències del Mar, Pg Marítim de la Barceloneta, 37-49, 08003 Barcelona, Spain, tel. (+34) 932399 500, FAX (+34) 932309555 


\section{Research highlights}

- We evaluated microbial pico- and nanoplankton diversity as an ecological indicator in NW Mediterranean coastal waters using metabarcoding of rRNA genes

- Studied samples were subjected to varying degrees of continental pressures

- Diversity metrics from microbial eukaryotic communities displayed more suitability to be used as indicators than those of prokaryotes

- Few microbial planktonic taxa (both from prokaryotes and eukaryotes) showed potential as indicators

- Implementing fast and simple ecological indicators from the diversity of these planktonic components is challenging due to the complexity and dynamics of the pelagic communities 


\section{Graphical abstract}

1

2 


\section{Abstract}

High-throughput sequencing of microbial assemblages has been proposed as an alternative methodology to the traditional ones used in marine monitoring and environmental assessment. Here, we evaluated pico- and nanoplankton diversity as ecological indicators in NW Mediterranean coastal waters by comparing their diversity in samples subjected to varying degrees of continental pressures. Using metabarcoding of the $16 \mathrm{~S}$ and $18 \mathrm{~S}$ rRNA genes, we explored whether alphadiversity indices, abundance of Operational Taxonomic Units and taxonomic groups (and their ratios) provide information on the ecological quality of coastal waters. Our results revealed that only eukaryotic diversity metrics and a limited number of prokaryotic and eukaryotic taxa displayed potential in assessing continental influences in our surveyed area, resulting thus in a restrained potential of microbial plankton diversity as an ecological indicator. Therefore, incorporating microbial plankton diversity in environmental assessment could not always result in a significant improvement of current marine monitoring strategies.

Keywords: Plankton diversity, high-throughput sequencing, coastal marine monitoring, ecological indicators, anthropogenic pressures, eutrophication 


\section{Introduction}

Oceans provide ecosystem services to society in a myriad of ways, from the regulation of the planet's climate to providing resources for human survival and well-being (Liquete et al., 2013). Human-modified coastal areas are experiencing increasing threats due to a continuously growing human population that accelerates resource use, waste production and environmental degradation. For instance, run-off of pollutants and nutrients arriving to coastal waters may alter natural ecosystems by changing productivity and food web dynamics or shifting species distributions among other impacts of unknown consequences (Halpern et al., 2007; Halpern et al., 2008; Hoegh-Guldberg and Bruno, 2010). All biological components of marine ecosystems may be affected by the consequences of human activities, from microbes to large animals (Davidson et al., 2012; Gall and Thompson, 2015; Cavicchioli et al., 2019). Given the importance of the marine ecosystem for the functioning of our planet and for our own welfare and its vulnerability to human impacts, there is a need to report on its condition and on the responses to the exerted pressures. In fact, numerous initiatives regarding the management of the marine environment have been or are being implemented worldwide in order to protect our seas and oceans (e.g., United Nations Convention on the Law of the Sea, the Marine Strategy Framework Directive in Europe or the Oceans Act in the USA, besides several local initiatives) (Birk et al., 2012).

The European Marine Strategy Framework Directive (MSFD, 2008/56/EC) requires European states to maintain their marine waters in 'Good Environmental Status' (GES). The MSFD includes 11 descriptors of GES: biological diversity, marine food webs, seafloor integrity, non-indigenous species introduction, fisheries, human-induced eutrophication, alteration of hydrographical conditions, concentrations of contaminants, contaminants in fish and other seafood, marine litter and introduction of energy and noise. For each descriptor, the status of the marine environment must be assessed using ecosystem criteria and indicators. There are currently multiple indicators being 
applied to the MSFD, some of them previously used under the European Water Framework Directive (WFD; 2000/60/EC), such as phytoplankton abundance and zoobenthos species composition, for eutrophication and biodiversity respectively (Borja et al., 2010; Camp et al., 2018). However, in the first case for example, the complexity of interactions between phytoplankton structure and physical, chemical and biological factors hinders the establishment of well-defined relationships between pressures and impacts, and therefore, effective management strategies. In fact, initial assessments during the first implementation phase of the MSFD revealed a general lack of operational indicators (Hummel et al., 2015) and thus, the need to develop alternative and innovative ones that can be implemented in a simple, fast and cheap manner (Caruso et al., 2015). In this regard, adding genetic diversity in marine monitoring is gaining attention and showing promising results, particularly in sediments. For example, the use of genomicbased indices has been proposed as an alternative to the macrobenthos biotic indices commonly applied to coastal waters (Aylagas et al., 2016; Pawlowski et al., 2018). Moreover, using microbial community composition has recently been considered in biomonitoring beyond the traditional use of fecal microorganisms as indicators of contamination (Caruso et al., 2015; Danovaro et al., 2016).

Marine microbes are essential in marine biogeochemical cycles and vital for the functioning of food webs, besides being substantial contributors to global marine biodiversity (Gasol and Kirchman, 2018). These organisms are known to respond rapidly to perturbations, such as increase in nutrient loads or events of acute contamination (Nogales et al., 2011). Placing microbial communities at the base of management decisions has gained attention in recent years, particularly after the advent of molecular approaches and high-throughput sequencing (HTS) that allow to overcome the limitation of identifying environmental microbes. A new and promising genomic-based microbial index was proven to correlate well with sediment quality and could be used to assess the ecological status of estuarine and coastal sediments (Aylagas et al., 2017). Likewise, diversity surveys of benthic bacterial and protist communities based on DNA sequencing 
seem to be useful in environmental assessments of fish farming, an industry having serious environmental impacts in marine habitats (Pawlowski et al., 2014; Stoeck et al., 2018).

Contrary to sediments, in which pollution is deposited and accumulated over time, pelagic ecosystems are much more dynamic which, comparatively, makes the determination of environmental status potentially more challenging. In fact, despite the increasing knowledge on the composition of plankton communities in recent times, their use for assessment of environmental status in marine waters is only beginning to be explored. Recently, Pearman et al. (2018) evaluated plankton communities in anthropogenically impacted oligotrophic coastal regions of the Red Sea and concluded that studying changes in the composition of microbial communities could be used to complement the existing approaches used to examine the multiple stresses affecting coastal areas. Nonetheless, given the limited information existing for pelagic ecosystems, more studies are required to better evaluate the usefulness of including small planktonic communities in the assessment of anthropogenic impacts in marine ecosystems.

In this study we explore pico- and nanoplankton diversity as an ecological indicator in the North-western Mediterranean coast. Beforehand, we had compared the performance of two distinct HTS methodologies to study marine picoplanktonic biodiversity and explored their use in ecosystem health assessment (Ferrera et al., 2016). This initial study revealed that certain taxa, as well as the ratio between the abundances of some bacterial groups, had potential for being useful indicators. Yet, the study was limited to a single location - the coast of Barcelona - at a single time point and more extensive surveys were needed to further evaluate the robustness of these findings. Here, we have tested the applicability of microorganisms as operational GES indicators in a survey of 6 locations across the Catalan and Balearic coasts subjected to varying degrees of continental pressures. In particular, we have explored whether diversity and richness indices, the relative abundance of OTUs (Operational Taxonomic Units) and taxonomic 
groups, as well as the ratios between the abundances of different planktonic groups respond to coastal impacts thus providing information on the ecological quality of NW Mediterranean coastal waters.

\section{Methods}

\subsection{Study sites.}

Surface water samples were collected from six locations located along the Catalan and Balearic coastal areas (Figure 1) that are representative of the NW Mediterranean coast in terms of geography, demography and socioeconomic activities. The choice of these coastal sites was based on previous characterization of the areas in the context of the Water Framework Directive (Table S1; Flo et al. 2011, 2017, 2019) and on Basterretxea et al. (2018). The six areas covered a variety of continental pressures and putatively receive variable nutrient loads and other pollutants from urban, industrial and agricultural activities (domestic waste, organic and inorganic nutrient enrichment among others). First, four cross-shore transects were undertaken in Palma de Mallorca, L'Estartit, L'Hospitalet de l'Infant and Barcelona. Sampling was conducted in summer (June-July 2014 for the Catalan Coast and July 2015 for the Balearic Coast) when temperatures are warm (see Table 1) and there is a lack of tidal mixing (Basterretxea et al., 2018). Palma $\left(39^{\circ} 32^{\prime} \mathrm{N} 2^{\circ} 43^{\prime} \mathrm{E}\right)$ is an intensive agricultural area in the island of Mallorca with reported nutrient rich groundwater seeps along the shoreline (Rodellas et al., 2014; TovarSánchez et al., 2014). The L'Estartit ( $\left.42^{\circ} 01^{\prime} \mathrm{N} 3^{\circ} 12^{\prime} \mathrm{E}\right)$ coastal area drains from a wetland with some agricultural activity and is also influenced by the Ter river, a low flow nitraterich Mediterranean river. L'Hospitalet de l'Infant $\left(40^{\circ} 58^{\prime} \mathrm{N} 0^{\circ} 54^{\prime} \mathrm{E}\right)$ is a sparsely populated region with dry land agriculture. While groundwater seeps from nearby coastal aquifers (Fernández Ruiz, 2012), nutrient concentrations along the coast are lower than at the previously mentioned agricultural areas. Barcelona is a hypothetically more impacted site since it is a highly developed urban area with a population of $\sim 3.2$ million inhabitants in the metropolitan area. From each of these four sites, $\sim 10$ surface samples were 
collected from the coastline to about 4-6 miles offshore. In the area of Barcelona, two additional cross-shore transects of 5 samples conducted in June and August 2013 around the PUDEM Coastal Ocean Observatory monitoring station (Arin et al., 2013) have been included in this study, one of them corresponding to the samples analyzed in Ferrera et al. (2016). Sampling cross-shore transects could reveal a continental pressure gradient even within samples collected in one area, since those taken near the coast are presumably more prone to be affected than the corresponding offshore samples. Besides these coast-to-offshore samplings, a transect of 4 stations was conducted in July 2014 in the estuarine Alfacs Bay, located in the Ebro Delta (40`38'N 0`43'E). This represents one of the most riverine-influenced areas of the Catalan coast and was selected to include samples subjected to a large agricultural influence.

In addition to these spatial gradients, samples from two time-series monitoring stations covering contrasting urban scenarios were included in the survey. The Blanes Bay Microbial Observatory $\left(41^{\circ} 40^{\prime} \mathrm{N} 2^{\circ} 48^{\prime} \mathrm{E}\right)$ is a coastal oligotrophic site subjected to low anthropogenic pressures (Gasol et al., 2016). The sampling station is located near the town of Blanes of $\sim 40.000$ inhabitants; natural disturbances are not frequent in this site since the closest river flows south of the monitoring station and its discharges are taken away by a predominantly south-west surface current. Samples collected from 2004 to 2013 were available for this study (but we excluded those from 2010-2012 due to construction of a nearby harbor during this period). The second location is the abovementioned PUDEM Station, off the coast of Barcelona. Samples collected at this site in 2014 were available for our study. Although monthly sampling is typically conducted in these two monitoring stations, only samples from June to September were used in the analyses to avoid natural seasonal variability from masking the potential differences found between areas. A total of 93 samples were included in the analyses. Basic environmental data associated to the samples are shown in Table 1.

\subsection{Sample collection}


About $2 \mathrm{~L}$ of $200-\mu \mathrm{m}$ pre-filtered surface seawater were collected and immediately transported to the laboratory where they were sequentially filtered through a $20-\mu \mathrm{m}$ mesh followed by a 3- $\mu \mathrm{m}$ and a $0.2-\mu \mathrm{m}$ pore-size polycarbonate filter (Poretics) using a peristaltic pump. The aim of the serial filtration was to obtain two different microbial size fractions, picoplankton from 0.2 to $3 \mu \mathrm{m}$ and nanoplankton from 3 to $20 \mu \mathrm{m}$. The size filtering separates eukaryotic organisms of different sizes, while in the case of prokaryotes it mostly separates free-living $(0.2-3 \mu \mathrm{m})$ from particle-attached $(3-20 \mu \mathrm{m})$ cells (Acinas et al., 1999). Filters were kept at $-80^{\circ} \mathrm{C}$ until processed. Cells were lysed using lysozyme, proteinase $\mathrm{K}$ and sodium dodecyl sulfate, and nucleic acids were extracted with phenol and concentrated in an Amicon 100 (Millipore), as described in Massana et al. (1997). The DNA was quantified spectrophotometrically (Nanodrop, Thermo Scientific), and a subsample was sent for sequencing to the Research and Testing Laboratory (rtlgenomics.com/).

A suite of environmental parameters was measured during sample collection. Temperature and salinity were measured with a CTD probe, the concentrations of inorganic nutrients were determined spectrophotometrically using an Alliance Evolution II autoanalyzer according to standard procedures (Grasshoff et al., 1983). In addition, distance to the coastline and freshwater content were taken into account in the analyses. Freshwater content was obtained from the salinity in the water in relation to the maximum salinity in the dataset as follows:

Freshwater content $=1000-(1000 * S) / \max (S)$ where $S$ is salinity

\subsection{Sequencing and sequence processing}

Both prokaryotes (i.e. Bacteria) and eukaryotes were amplified from the two size fractions collected. Primers 341F (5'-CCTACGGGNGGCWGCAG-3'; Herlemann et al., 2011) and 806RB (5'-GGACTACNVGGGTWTCTAAT-3'; Apprill et al., 2015) were used to amplify the V3-V4 region of the bacterial 16S rRNA gene, whereas eukaryotic primers TAReuk454FWD1 (5'-CCAGCASCYGCGGTAATTCC-3') and TAReukREV3 (5'- 
ACTTTCGTTCTTGATYRA-3') (Stoeck et al., 2010) were used to amplify the V4 region

of the $18 \mathrm{~S}$ rRNA gene. Amplicons were sequenced in an Illumina MiSeq $2 \times 250$ flow cells following protocols described elsewhere (Cúcio et al., 2016).

Illumina reads of both $16 \mathrm{~S}$ and $18 \mathrm{~S}$ rRNA genes underwent quality filtering before being analyzed through a custom made pipeline (Logares, 2017). Spades software (Nikolenko et al., 2013) was used to correct errors that may had arisen in the sequencing process; R1 (forward) and R2 (reverse) reads were merged using Pear (Nurk et al., 2013) and the resulting sequences were filtered by quality (expected errors per sequence did not exceed 1) with USEARCH. Then, all reads were put into the same direction using a Hidden Markov Model, concatenated, dereplicated with USEARCH and sorted by abundance. Subsequently, reads were clustered into OTUs (Operational Taxonomic Units) using $97 \%$ similarity threshold for prokaryotes and $99 \%$ for eukaryotes, and possible chimeras were filtered using the version 119 of the SILVA SSU non-redundant database as reference. Singletons were also discarded as a pre-emptive measure to remove OTUs putatively deriving from sequencing errors. Next, the OTU table was generated and OTUs were taxonomically classified by using BLAST against SILVA v119 for prokaryotes and an in-house database for eukaryotes (EukaryotesV4 database; Obiol et al., 2020). Subsequently, all OTUs classified as chloroplast, mitochondria or Archaea, in the case of prokaryotes, and Metazoan, Streptophyta or Nucleomorphs in the case of eukaryotes, were removed. After filtering, the OTU reads for each sample were rarefied to 5000 reads and the resulting table was used for the diversity and richness indices, whereas the other analyses were carried out using the OTU table with relative abundances. OTUs were collapsed into the main prokaryotic (i.e. bacterial) and eukaryotic taxonomic groups when needed to explore the relative contribution of each group.

\subsection{Data analyses}

An arcsine, or angular, transformation was applied to the OTU relative abundances in the non-rarefied table. This transformation equals to the inverse sine of the square root 
of the proportion transformed again from radians to a proportion value, or:

$$
2 / \pi * \arcsin (\sqrt{ } p)
$$

where $p$ is the relative abundance of an OTU. The arcsine transformation spreads the ends of the scale while compressing the middle, and is recommended by many statisticians for proportion data, often improving normality (Sokal and Rohlf, 1995).

In order to categorize the stations depending on their degree of anthropic pressure, we used the FLU and FAN methods developed and validated by Flo (2017) in the same study area. FLU is an abbreviation of FLUviality and FAN is the acronym of phosphate (Fosfat in Catalan), Ammonium, and Nitrite. The approach uses physicochemical variables to assess continental urban and fluvial influences in a given site. The method is based on the following assumptions: i) the main pressures on coastal waters are continental influences, which are linked to freshwater inflows and to the nutrients they release into coastal waters, ii) continental influences, through their nutrient contributions, trigger the production of chlorophyll a in coastal waters, which may enhance eutrophication, and iii) continental influences on coastal waters can be of urban or fluvial origin. The FLU index, computed mainly based on silicate and nitrate levels as well as on freshwater content (FWC) describes a gradient related to fluvial continental influences. The FAN index mainly reflects phosphate, ammonium, and nitrite levels and describes a gradient related to urban continental influences of anthropogenic origin. The method was validated along the Catalan coast using a large time series dataset (1994-2014, $\mathrm{N}=18,102$ ) and can be applied at different spatial and temporal scales and is reproducible, allowing comparisons across geographical areas and study periods. The indices were calculated following the formulas from Flo (2017):

FLU index $=0.86{ }^{\star} \mathrm{NO}_{3}-0.37^{\star} \mathrm{NO}_{2}-0.52^{\star} \mathrm{NH}_{4}-0.89^{\star} \mathrm{PO}_{4}+1.15^{\star} \mathrm{SiO}_{4}+0.87^{\star} \mathrm{FWC}-2.00$

FAN index $=-0.19^{\star} \mathrm{NO}_{3}+2.86^{\star} \mathrm{NO}_{2}+1.42^{\star} \mathrm{NH}_{4}+2.91^{\star} \mathrm{PO}_{4}-0.27^{\star} \mathrm{SiO}_{4}-0.35^{\star} \mathrm{FWC}-0.60$

Based on the values of both indices, all samples were classified into three categories 
(Low, Medium and High) according to the quartile to which they belong. The values belonging to the first quartile were classified as Low, the ones belonging to the two central quartiles as Medium and the ones belonging to the highest quartile were classified as High (Figure S1).

Statistical analyses were performed using the $R$ statistical software ( $R$ Development Core Team, 2015) and the packages ggplot2, reshape2, phyloseq, magrittr, labdsv, tidyverse, dendextend, ggfortify, FactoMineR, lubridate, vegan and dplyr. The Shannon and Chao1 indices, for diversity and for richness estimation respectively (Magurran 1988; Chao and Lee, 1992), were calculated for both plankton size fractions of prokaryotes and eukaryotes. These indices are of common use and were obtained through the phyloseq package in R. The values were grouped according to the FLU and FAN index category that each sample falls into. For community structure analyses, we used the vegan package. A dissimilarity matrix (Bray-Curtis) was constructed based on the rarefied OTU table with the vegdist function. Patterns of community structure were visualized using metaMDS. Additionally, we tested for significant relationships between environmental variables and the nMDS ordination of samples using the envfit function. Permutational tests (adonis) were employed to examine community differences among sampling areas. Potential indicator OTUs or taxonomic groups were also explored by calculating the Pearson correlation coefficient between the relative abundance of each OTU or taxonomic group and the FLU and FAN values, as well as the concentration of nutrients in the water samples. Additionally, Indicator Value (IndVal; Dufrêne and Legendre, 1997), which use species (or OTU) fidelity and relative abundance to identify indicator species, were calculated in order to identify potential indicators for the three categories (Low, Medium or High) of the impact indices. The tests were carried out separately for each size fraction, since organisms belonging to the same taxonomic group but with substantially different sizes or lifestyles could respond differently to environmental changes. The $p$ values were corrected through the Holm-Bonferroni method (Holm, 1979) for the number of taxonomic units being tested for potential correlations with nutrient concentrations or impact 
index values, in order to avoid having spurious significant $p$-values as a consequence of the

high number of tests performed. The IndVal results were capped at $p$-value $<0.05$ and IndVal value $>0.3$, since this is the value that has been proposed as a threshold for indicating habitat specialization (Dufrêne and Legendre 1997). The results were also filtered by the relative abundance of the analyzed OTUs or taxonomic groups, with a threshold of $0.4 \%$ as in Ferrera et al. (2016) since the potential as indicator species of rare OTUs is questionable considering the differences found between sequencing methods (Ferrera et al. 2016) and the known biases of the PCR-based methodologies (Polz and Cavanaugh, 1998). Analysis of variance was used to test for differences in the relative abundance of different taxa depending on the impact index category. $P$ values were adjusted by the number of ANOVAs performed. Sequence data has been submitted to the European Nucleotide Archive (www.ebi.ac.uk/ena) under accession numbers PRJEB23788, PRJEB38773, PRJEB38800 and PRJEB38808.

\section{Results}

Impact indices. For the purpose of categorizing the samples in relation to continental pressures, two impact indices were calculated: the FLU and the FAN indices (Table 1). The values were plotted by location (Figure 2); FLU and FAN values were significantly different among sampling locations (ANOVA, $p$ values $=1.76 \mathrm{e}^{-11}$ and $2.88 \mathrm{e}^{-13}$ respectively). In particular, samples from Alfacs, L'Estartit and L'Hospitalet de l'Infant displayed higher FLU values than other locations. These sites are located in areas with either riverine (Alfacs, L'Estartit) or groundwater (Alfacs, L'Hospitalet de l'Infant) influence. At the same time, these three locations displayed much lower FAN values than in other locations, being the differences statistically significant from those from Barcelona and Blanes (Tukey HSD test at $p<0.05)$. FAN values for Barcelona and Blanes were however within the same range despite the diverging continental pressures expected. Palma presented somewhat intermediate FLU and FAN values (indicating a mixed influence of urban and freshwater pressures). The values of the indices were pooled and classified into Low, Medium and High categories (see Materials and 
Methods, Figure S1) in order to explore the response of the biological variables (i.e. diversity data) in relation to these indices. Most samples from Alfacs, L'Estartit and L'Hospitalet de l'Infant fell within the High category of the FLU index. Barcelona and Palma samples belonged mainly to the Medium impact category. For Blanes, FLU values were variable; while many samples fell into the Low category, some of them also belonged to the Medium or High categories. The opposite trend was observed for the FAN index from Alfacs, L'Estartit and L'Hospitalet de l'Infant that fell mostly in the Low FAN category. As for the FLU index, Palma samples were categorized as Medium FAN impact, while Barcelona and Blanes samples were distributed between the Medium and High FAN impact categories.

Diversity indices. Biological diversity is one of the descriptors included in the European MSFD for the assessment of 'Good Environmental Status'. We thus explored whether common alphadiversity metrics (i.e. Chao1 index for richness and Shannon index for diversity) were related to the computed FLU and FAN indices (Figures 3 and 4). For prokaryotes, Chao1 and Shannon indices displayed higher values for the particleattached bacteria (nanoplankton fraction) than for the free-living one (picoplankton), regardless of the category of the FLU or FAN indices. The response of the alphadiversity indices to the degree of impact estimated by the FLU and FAN indices was however little. No significant differences were found for alphadiversity indices of prokaryotes (neither for the free-living nor for the particle-attached bacteria) as a function of the FLU or FAN categories (ANOVA, p>0.05, Figure 3a). Compared to prokaryotes, eukaryotes displayed overall higher values of alphadiversity. Eukaryotic nanoplankton presented higher Chao1 values than picoplankton but this trend was not observed for the Shannon diversity values (Figure 4). As for the differences in relation to the impact indices, greater differences were observed for eukaryotes than for prokaryotes. In particular, significant differences were found for picoplankton in Chao1 and Shannon indices for the different categories of the FLU (ANOVA, $p=5.82 \mathrm{e}^{-03}$ and $p=9.36 \mathrm{e}^{-04}$ respectively) and FAN (ANOVA, $p=4.59 \mathrm{e}^{-05}$ and $p=3.50 \mathrm{e}^{-05}$ respectively) indices whereas these differences 
were only significant for Shannon diversity in the nanoplankton fraction (ANOVA, $p=2.85 \mathrm{e}^{-03}$ and $p=4.22 \mathrm{e}^{-04}$ for FLU and FAN, respectively). Interestingly, contrary to prokaryotes, lower values of alphadiversity corresponded to higher values of the FLU index while the FAN categories followed the opposite trend.

Community structure. Non-metric multidimensional scaling indicated that the sampling area had a certain role in structuring plankton assemblages in all components (prokaryotic and eukaryotic) and size fractions (pico- and nanoplankton) analysed here (Figure S2), an observation confirmed by permutational analyses that showed that it explained $22 \%$ to $36 \%$ of the variation $(p<0.001)$. For prokaryotic communities, samples from Barcelona generally showed the least delineated clustering while communities from L'Hospitalet de l'Infant formed the most defined one. A different pattern was observed for eukaryotes; while eukaryotic picoplankton from Blanes showed the highest dissimilarity to other communities, eukaryotic nanoplankton assemblages from this sampling station were similar to those from other areas, while those assemblages from Barcelona were highly dissimilar. Fitting of environmental factors to the nMDS ordination revealed an effect of various variables. While silicate and nitrate concentration correlated significantly to the structure of all assemblages analyzed, phosphate concentration and temperature only showed significant correlation with particular assemblages. The FAN index correlated with prokaryotes from the nanoplankton and the eukaryotic picoplankton fractions, while the FLU index was significant only with the former. No significant correlations were found between these impact indices and the rest of assemblages (Figure S2).

Potential indicator taxa. Given that microbes respond rapidly to variations in environmental conditions, including nutrient inputs, we explored whether the relative abundances of the occurring taxa were related to the impact indices, both at the broad taxonomic group and at the OTU level. Figure 5 shows the relative contribution of major prokaryotic and eukaryotic taxa to planktonic community structure grouped by the category of the impact indices that the samples belong to (Low, Medium or High 
categories of FLU and FAN). Although no major changes in the taxonomic composition of the samples were observed regardless of their category, analysis of variance revealed that significant differences existed for the Actinobacteria, Rickettsiales (Alphaproteobacteria) and Sphingobacteriia (Bateroidetes) in relation to the FLU and FAN categories (Figure S3, Table S2). Within the eukaryotic taxa, analyses of variance only revealed significant differences in the abundance of the Basal Fungi (Opisthokonta) in the nanoplankton size in relation to the impact indices. Besides, we tested for differences at the OTU level and only found positive correlations between a nanoeukaryotic OTU affiliated to Gymnodinium litoralis (Dinoflagellata) and the concentrations of phosphate, nitrate and silicate $\left(\mathrm{N}=36, R>0.5, p<1 \mathrm{e}^{-13}\right.$, Table S3).

We further explored potential 'indicator taxa' through the Indicator Value (IndVal) from Dufrêne and Legendre (1997). This value identifies indicator taxa fidelity and relative abundance and is a popular measure to express taxa importance in community ecology. Likewise, its potential to reflect environmental quality has been explored in biodiversity surveys (Ferrera et al., 2016; Lumbreras et al., 2016; Cordier et al., 2020). A total of 9 prokaryotic and 6 eukaryotic taxonomic groups were found with significant IndVal and relative abundances higher than $0.4 \%$ (Table 2). These groups have explanatory power mostly for either the Low and High categories of the impact indices, and most often for the FLU index (Table 2). More significant IndVal were detected among the prokaryotes than the eukaryotes. Moreover, significant IndVal were found in the two analyzed size fractions of the prokaryotic dataset but only in the picoplankton fraction of the eukaryotes. Most prokaryotic indicator taxa of the High FLU impact were at the same time indicators of the Low FAN index category (i.e., the Actinobacteria, Planctomycetes and Sphingobacteriia). Additionally, the Flavobacteriia were indicator only for the FLU index (Medium impact). For eukaryotes, the Rhizaria (Cercozoa) and Stramenopiles (MAST-3 and MAST-4) appeared as potential indicators for the Low category of the FLU index while the Telonema (Hacrobia) were indicator for the High category of this index and, at the same time, for the Low FAN impact category. 
Besides the concept of indicator species or taxa, the potential of quality indicators based on the ratio of different taxa was investigated. In particular, we explored the ratios of the bacterial groups Alphaproteobacteria / Gammaproteobacteria, Alteromonas / SAR11, and Alteromonas + Oceanospirillales / SAR11 that had been proposed in our previous work (Ferrera et al., 2016) together with various alternative potential indices based on the abundance of those groups that appeared as indicator taxa. We found that, from all those tested, only the ratio Actinobacteria / Rickettsiales, calculated by dividing the relative abundances of Actinobacteria by that of Rickettsiales in the picoplankton fraction, was higher at high FLU values (Figure 6). No ratios with indicator potential were found within the eukaryotes.

\section{Discussion}

We explored the informative potential of pico- and nanoplankton communities for environmental status assessment using pelagic samples collected from diverse areas of the NW Mediterranean. As recently reviewed by Cordier et al. (2020), various strategies to explore indicators based on environmental genetic data exist. Here, we explored the socalled 'structural community metrics strategy' by examining the potential of diversity and richness indices, and the 'de novo strategy' aimed at discovering new indicators of environmental status in the water column by analyzing the abundances of OTUs and taxonomic groups (and their ratios). To do so, we classified the sampled stations based on the FLU and FAN impact indices, which indicate the origin of the land influences to the coast, derived from physicochemical variables as previously described (Flo 2017) and explored whether the biological variables responded to them. These indices were developed to distinguish between natural and cultural eutrophication, which is key to management planning. The FLU index clearly distinguished samples from Alfacs Bay and L'Estartit, both influenced by rivers, as well as from L'Hospitalet de l'Infant which could be explained by the presence of nearby groundwater seeps (Fernández-Ruiz 2012, Basterretxea et al., 2018). Likewise, the FAN values were overall different among sites but varied slightly between Blanes and Barcelona despite these are a small and a large 
city, respectively. In any case, the highest values were found for samples off the coast of Barcelona, particularly those closest to shore (Figure S4). Contrarily, samples collected at $200 \mathrm{~m}$ from the coast line of Barcelona showed values within the range of low populated areas (Figure S4). The lack of differences between these sites may be related to the implementation of policies to reduce the impact of urban areas on coastal systems (i.e., wastewater treatment plants, sewage management, etc.) that combined with natural processes challenge the reliable discrimination between natural variability and human effects in the water column. For instance, one station statistically considered to be in good environmental status can episodically present low values of water quality (in our case would be reflected by high FAN values) that fall within the range of the best values from another location considered to be in bad environmental status, and vice versa. The large variability of FAN values from for Blanes and Barcelona could be examples of this scenario.

The measurement of species diversity of an ecosystem has been proposed as a useful tool for assessing the impacts of human activities on marine ecosystems. The strategy based on community metrics aims at discovering and understanding the ecological processes shaping communities and their response to disturbances (see Cordier et al., 2020). Actually, the results of our previous work (Ferrera et al., 2017) indicated that it could be worth exploring the links between microbial diversity and environmental status of coastal waters. Here, we found that both Chao1 and Shannon indices from eukaryotic communities showed power as indicators for assessing continental influences. These findings are contrary to those reported by Pearman et al. (2018) that found no differences in alphadiversity in a study assessing plankton community in anthropogenic-impacted coastal regions of the Red Sea. Likewise, opposed results have been reported in marine sediments; alphadiversity has been found to decrease in bacterial communities impacted by aquaculture (Stoeck et al., 2018) but disturbances can also trigger increases in bacterial diversity (Galand et al., 2016). These results evidence that the complexity of microbial plankton communities 
implementation of diversity metrics for environmental monitoring should be conducted in combination with other community and environmental characteristics.

\section{Community structure analyses revealed an influence of the sampling area and of certain} environmental factors on the structuring of plankton assemblages. Moreover, differences in the abundance of certain taxa were observed in relation to nutrient values and impact indices. Both prokaryotes and eukaryotes showed potential as indicators. Within the prokaryotes, the relative abundance of Actinobacteria in the picoplankton displayed the highest Indicator Value, particularly as indicator of the High category of the FLU and the Low FAN impact indices. Actinobacteria, are widely distributed in both terrestrial and aquatic (marine and freshwater) ecosystems. Genomic analyses reveal a remarkable potential capacity to transform recalcitrant detrital material, particularly lignin-derived compounds, suggesting close linkages between the terrestrial and aquatic realms (Ghai et al., 2014). Their correlation with high FLU and low FAN values may indicate that these organisms are transported from freshwater to coastal ecosystems. Likewise, the Sphingobacteria that presented a significant IndVal in samples of High FLU and Low FAN categories are capable of degrading polymeric matter (Bergauer et al., 2018). Within the eukaryotes, our results indicate that abundances of an OTU attributed to the dinoflagellate Gymnodinium litoralis were positively correlated with concentrations of nitrate, silicate and phosphate. This species is known to produce recurrent near-shore high-biomass blooms in L'Estartit (Reñé et al., 2011), an area shown to have riverine influence and high availability of these inorganic nutrients (Tables 1 and S1). At broad taxonomic levels, Basal Fungi (Ophisthokonta) from nanoplankton were correlated with nitrate, silicate and phosphate. This lineage comprises a diverse group of heterotrophic, saprophytic and parasitic organisms, including the Chytridiomycota that contains many parasites of phytoplankton (Frenken et al., 2017, Grossart et al., 2019). The fact that they show positive correlations with inorganic nutrients could reflect their coupling with the higher abundances of potential hosts, like dinoflagellates. Likewise, other eukaryotic taxa exhibit significant IndVal scores confirming the potential to unveil indicators through 
the 'de novo approach'. Among these, the Chlorodendrophyceae (Archaeplastida) were indicator for samples subjected to low FAN and high FLU impacts. This group of prasinophytes (green algae) can be abundant in certain Mediterranean coastal stations (Tragin and Vaulot, 2018). Given their IndVal score in stations linked to a gradient of freshwater content as well as nitrate and silicate concentrations, their presence could be related to natural continental influences of fluvial origin. The uncultured marine stramenopiles MAST-3 and MAST-4 also displayed significant IndVal scores. These clades represent heterotrophic small protists that appear as common members in molecular surveys of marine picoplankton (Massana et al., 2004). Noteworthy, these taxa were indicative of water under low FLU impact (that is low freshwater, nitrate and silicate content). While certain clades of MAST have shown preference for brackish or freshwater environments, MAST-3 and MAST-4 have a clear preference for marine waters (Massana et al., 2014).

Besides indicator species or taxa, the potential of using the ratio between different groups of microorganisms as an alternative indicator of environmental status has been proposed (Garrido et al., 2014). In fact, in our previous survey we concluded that some bacterial indices, i.e. the ratio of Alphaproteobacteria / Gammaproteobacteria, Alteromonas / SAR11 and Alteromonas + Oceanospirillales / SAR11 could potentially become new tools in marine monitoring (Ferrera et al., 2016). Despite the promising results found in that proof-of-concept study, here we found that when comparing a range of conditions and accounting for certain temporal variation, these indices lost significance. Contrarily, the Actinobacteria / Rickettsiales ratio appeared to be correlated with the FLU index, and could potentially reflect continental pressures, particularly associated to areas of riverine influence (i.e., Alfacs and L'Estartit). On the other hand, no ratios with indicator potential were found within the small eukaryotes (up to $20 \mu \mathrm{m}$ ) although previous studies have claimed the potential of protists as indicators (see Pawlowski et al., 2018). This lack of consistency highlights the difficulty of finding operational indicators that can be widely used. 
Metabarcoding of environmental DNA provides a cost efficient approach for biodiversity monitoring and overcome many of the problems associated with traditional monitoring, offering the possibility to explore the use of microorganisms as bioindicators. In fact, its application has resulted in promising results in areas subjected to acute contamination but also along eutrophication gradients, particularly in sediments (Pawlowski et al., 2014; Aylagas et al., 2017; Stoeck et al., 2018). Although potential bioindicators were also unveiled in our study, the results are not as striking as those recently published by others. The structure and composition of the studied planktonic communities changed only slightly in areas of riverine influence and the shifts were even more negligible among sites under contrasting degrees of urban influence, represented by elevated values of nitrite and ammonia. A possible explanation for the differences in our results and those by other authors is the range of environmental pressures evaluated. Even though our study covers contrasting locations in terms of continental pressures, from hardly populated sites to the large city of Barcelona, the evaluated pressures here may have been more restrained. The study of Pearman et al. (2018) compared nearly pristine sites to areas impacted by a wastewater treatment plant effluent or the pressure from container ships calling the port of Jeddah, Saudi Arabia, and were able to detect taxa associated to sewage or fecal matter. Likewise, the microgAMBI (Aylagas et al., 2017) index was developed for the evaluation of anthropogenic impacts occurring in sediments subjected to a wide range of human pressures derived from industrial activities such as the presence of metals and chemical pollutants (PCB among others). Our study, moreover, covers from nearshore coastal sites to offshore stations and, even though we limited our study to end of spring and summer, we observed certain spatial and temporal variability in the FLU and FAN index values in each location (see Figures 2 and S4), supporting the known difficulties of setting ecological status boundaries in areas subjected to moderate degrees of impacts. It is possible that the natural spatial and seasonal variability (succession of continually changing communities) of the studied area may be constraining the potential of pico- and nanoplankton as indicators. A good biodiversity indicator should be able to distinguish the anthropogenic impact from natural 
variability (Borja et al., 2012). Microbial communities are known to display natural seasonality (Furhman et al., 2015; Auladell et al., 2019; Giner et al., 2019) which may challenge using these assemblages in environmental assessments unless baseline conditions are well known. In fact, community composition cannot be used as a quality indicator in an absolute sense but only in relation with known environmental conditions, and thus, previous information on the natural spatial and temporal variability of an area is necessary to establish a baseline of knowledge that allows to discriminate the natural from the human-derived variability. Yet, an operational indicator by definition must be implemented in a simple, fast and cheap manner. Requiring large efforts to establish a knowledge baseline for an indicator compromises its usefulness, which could be the case for pico- and nanoplankton, at least based in our results. Further yet, a recent study conducted in the Bay of Pozzuoli (Gulf of Naples, Mediterranean Sea) found that phytoplankton and prokaryotes showed a limited response to anthropogenic pressures and suggest that planktonic animals could in fact be better sentinels of impact (Margiotta et al., 2020).

Traditionally, with the exception of fecal indicators, microbes have not been used as indicators due to the difficulties in the taxonomic identification of environmental microorganisms. Nowadays, the use of sequencing technologies overcomes these limitations and allow to assess microbial community patterns in coastal regions in a faster and cheaper manner. In that sense, microbes have been proposed as indicators of marine environmental quality because they are known to react quickly to environmental changes, which makes them sensitive to disturbances. At the same time, however, communities have a large resilience and they are able to recover fast if the pressure is not permanent. As a result, in highly dynamic environments such as the pelagic realm, the small organisms of the plankton compartment may bear short-term memory of impact events and be poor indicators of environmental status, at least in areas of moderate impact. We thus conclude that in spite of the usefulness of environmental genomic-based approaches for biodiversity monitoring, translating pico- 
and nanoplankton diversity into fast and simple ecological indicators is challenging, in part due to the complexity and dynamics of these pelagic communities. Increasing our knowledge on plankton species responses to the natural environmental could however strengthen their potential as ecological indicators.

\section{Acknowledgments}

This work is an outcome of the DEVOTES (Development of innovative tools for understanding marine biodiversity and assessing GEnS) project, funded by the European Union (grant agreement $n^{\circ}$ 308392), and the Spanish grant GRADIENTS (Fine-scale structure of cross-shore gradients along the Mediterranean coast, CTM201239479-C02). We thank all the people involved in running the Blanes Bay Microbial Observatory and the PUDEM Coastal Ocean Observatory (http.//coo.icm.csic.es/) for making the sampling possible and providing ancillary data. The Marine Bioinformatics Platform at ICM-CSIC (MARBITS; https://marbits.icm.csic.e) and particularly Dr. Ramiro Logares provided help with computing analyses. We also thank Elisabet Alacid, Silvia Anglès, Gotzon Basterretxea, Eva Flo, Antoni Jordi, Nagore Sampedro and Marta Turon for help with sampling and basic analyses, Vanessa Balagué for help extracting DNA and Natalia Timoneda for help with sequence submission to ENA.

\section{Author statement}

Isabel Ferrera: Conceptualization, Methodology, Investigation, Validation, Writing original draft, Reviewing, Editing; Albert Reñé: Conceptualization, Methodology, Investigation, Reviewing, Editing; David Funosas: Software, Analysis, Writing; Jordi

Camp: Conceptualization, Resources, Reviewing; Ramon Massana: Resources, Reviewing; Josep M Gasol: Resources, Reviewing; Esther Garcés: Conceptualization, Resources, Reviewing, Editing

\section{References}

Acinas, S.G., Antón, J., Rodríguez-Valera, F., 1999. Diversity of free-living and attached bacteria in offshore western Mediterranean waters as depicted by analysis of genes 
encoding 16S rRNA. Appl. Environ. Microbiol. 65, 514-522.

https://doi.org/10.1128/aem.65.2.514-522.1999

Apprill, A, McNally, S., Parsons, R., Weber, L., 2015. Minor revision to V4 region SSU rRNA 806R gene primer greatly increases detection of SAR11 bacterioplankton. Aquat. Microb. Ecol. 75, 129-137. https://doi.org/10.3354/ame01753

Arin, L., Guillén, J., Segura-Noguera, M., Estrada, M., 2013. Open sea hydrographic forcing of nutrient and phytoplankton dynamics in a Mediterranean coastal ecosystem. Estuar. Coast. Shelf Sci. 133, 116-128. https://doi.org/10.1016/j.ecss.2013.08.018

Auladell, A., Sánchez, P., Sánchez, O., Gasol, J.M., Ferrera, I., 2019. Long-term seasonal and interannual variability of marine aerobic anoxygenic photoheterotrophic bacteria, ISME Journal 13(8), 1975-1987. https://doi.org/10.1038/s41396-019-0401-4

Aylagas, E., Borja, Á., Irigoien, X., Rodríguez-Ezpeleta, N., 2016. Benchmarking DNA Metabarcoding for Biodiversity-Based Monitoring and Assessment. Front. Mar. Sci. 3, 1-12. https://doi.org/10.3389/fmars.2016.00096

Aylagas, E., Borja, Á., Tangherlini, M., Dell'Anno, A., Corinaldesi, C., Michell, C.T., Irigoien, X., Danovaro, R., Rodríguez-Ezpeleta, N., 2017. A bacterial communitybased index to assess the ecological status of estuarine and coastal environments. Mar. Pollut. Bull. 114, 679-688. https://doi.org/10.1016/i.marpolbul.2016.10.050

Basterretxea, G., Torres-Serra, F.J., Alacid, E., Anglès, S., Camp, J., Ferrera, I., Flo, E., Font-Muñoz, J.S., Jordi, A., Reñé, A., Salgado-Hernanz, P.M., Sampedro, N., Garcés, E., 2018. Cross-shore environmental gradients in the Western Mediterranean coast and their influence on nearshore phytoplankton communities. Front. Mar. Sci. 5, 78. https://doi.org/10.3389/fmars.2018.00078

Bergauer, K., Fernandez-Guerra, A., Garcia, J.A.L., Sprenger, R.R., Stepanauskas, R., Pachiadaki, M.G., Jensen, O.N., Herndl, G.J., 2018. Organic matter processing by microbial communities throughout the Atlantic water column as revealed by metaproteomics. Proc. Natl. Acad. Sci. U. S. A. 115, E400-E408. https://doi.org/10.1073/pnas.1708779115

Birk, S., Bonne, W., Borja, A., Brucet, S., Courrat, A., Poikane, S., Solimini, A., Van De Bund, W., Zampoukas, N., Hering, D., 2012. Three hundred ways to assess Europe's surface waters: an almost complete overview of biological methods to implement the Water Framework Directive. Ecol. Indic. 18, 31-41. https://doi.org/10.1016/j.scitotenv.2019.02.251

Borja, Á., Dauer, D.M., Grémare, A., 2012. The importance of setting targets and reference conditions in assessing marine ecosystem quality. Ecol. Indic. 12, 1-7. https://doi.org/10.1016/j.ecolind.2011.06.018

Borja, Á., Elliott, M., Carstensen, J., Heiskanen, A.-S., van de Bund, W., 2010. Marine management-towards an integrated implementation of the European Marine Strategy Framework and the Water Framework Directives. Mar. Pollut. Bull. 60, 2175-2186. https://doi.org/10.1016/j.marpolbul.2010.09.026

Camp, J., Flo, E., Vila, M., Arin, L., Reñé, A., Sampedro, N., Manzanera, M., Garcés, E., 2006. Pros and Cons of Biological Quality Element Phytoplankton as a WaterQuality Indicator in the NW Mediterranean Sea, in: Handbook of Environmental Chemistry. pp. 1-12. https://doi.org/10.1007/698

Caruso, G., La Ferla, R., Azzaro, M., Zoppini, A., Marino, G., Petochi, T., Corinaldesi, C., Leonardi, M., Zaccone, R., Fonda Umani, S., Caroppo, C., Monticelli, L.S., Azzaro, F., Decembrini, F., Maimone, G., Cavallo, R.A., Stabili, L., Hristova Todorova, N., K. Karamfilov, V., Rastelli, E., Cappello, S., Acquaviva, M.I., Narracci, M., De Angelis, R., Del Negro, P., Latini, M., Danovaro, R., 2015. Microbial assemblages for environmental quality assessment: Knowledge, gaps and usefulness in the European Marine Strategy Framework Directive. Crit. Rev. Microbiol. 7828, 1-22. https://doi.org/10.3109/1040841X.2015.1087380

Cavicchioli, R., Ripple, W.J., Timmis, K.N., Azam, F., Bakken, L.R., Baylis, M., Behrenfeld, M.J., Boetius, A., Boyd, P.W., Classen, A.T., Crowther, T.W., 
Danovaro, R., Foreman, C.M., Huisman, J., Hutchins, D.A., Jansson, J.K., Karl, D.M., Koskella, B., Mark Welch, D.B., Martiny, J.B.H., Moran, M.A., Orphan, V.J., Reay, D.S., Remais, J. V., Rich, V.I., Singh, B.K., Stein, L.Y., Stewart, F.J.,

Sullivan, M.B., van Oppen, M.J.H., Weaver, S.C., Webb, E.A., Webster, N.S., 2019. Scientists' warning to humanity: microorganisms and climate change. Nat. Rev. Microbiol. 17, 569-586. https://doi.org/10.1038/s41579-019-0222-5

Chao, A., Lee, S.-M., 1992. Estimating the Number of Classes via Sample Coverage. J. Am. Stat. Assoc. 87, 210-217. https://doi.org/10.1080/01621459.1992.10475194

Cordier, T., Sáez, L.A., Apotheloz-Perret-Gentil, L., Aylagas, E., Bohan, D.A., Bouchez, A., Chariton, A., Creer, S., Fruhe, L., Keck, F., 2020. Ecosystems Monitoring Powered by Environmental Genomics: A Review of Current Strategies with An Implementation Roadmap. https://doi.org/10.1111/mec.15472

Cúcio, C., Engelen, A.H., Costa, R., Muyzer, G., 2016. Rhizosphere Microbiomes of European + Seagrasses Are Selected by the Plant, But Are Not Species Specific.

Front. Microbiol. 7, 1-15. https://doi.org/10.3389/fmicb.2016.00440

Danovaro, R., Carugati, L., Berzano, M., Cahill, A.E., Carvalho, S., Chenuil, A., Corinaldesi, C., Cristina, S., David, R., Dell'Anno, A., Dzhembekova, N., Garcés, E., Gasol, J.M., Goela, P., Féral, J.-P., Ferrera, I., Forster, R.M., Kurekin, A.A., Rastelli, E., Marinova, V., Miller, P.I., Moncheva, S., Newton, A., Pearman, J.K., Pitois, S.G., Reñé, A., Rodríguez-Ezpeleta, N., Saggiomo, V., Simis, S.G.H., Stefanova, K., Wilson, C., Martire, M.L., Greco, S., Cochrane, S.K.J., Mangoni, O., Borja, A., 2016. Implementing and innovating marine monitoring approaches for assessing marine environmental status. Front. Mar. Sci. 3. https://doi.org/10.3389/fmars.2016.00213

Davidson, A.D., Boyer, A.G., Kim, H., Pompa-Mansilla, S., Hamilton, M.J., Costa, D.P., Ceballos, G., Brown, J.H., 2012. Drivers and hotspots of extinction risk in marine mammals. Proc. Natl. Acad. Sci. 109, 3395-3400.

https://doi.org/10.1073/pnas.1121469109

Directive, Marine Strategy Framework. "Directive 2008/56/EC of the European Parliament and of the Council of 17 June 2008 establishing a framework for community action in the field of marine environmental policy." Official Journal of the European Union L 164 (2008): 19-40.

Directive, Water Framework. "Directive 2000/60/EC of the European Parliament and of the Council of 23 October 2000 establishing a framework for Community action in the field of water policy." Official journal of the European communities 22.12 (2000).

Dufrêne, M., Legendre, P., 1997. Species assemblages and indicator species: The need for a flexible asymmetrical approach. Ecol. Monogr. 67, 345-366. https://doi.org/10.1890/0012-9615(1997)067[0345:SAAIST]2.0.CO;2

Fernández Ruiz, L., 2012. Las aguas subterráneas en la planificación hidrogeológica. Instituto Geológico y Minero de España. Madrid, 481.

Ferrera, I., Giner, C.R., Reñé, A., Camp, J., Massana, R., Gasol, J.M., Garcés, E., 2016. Evaluation of Alternative High-Throughput Sequencing Methodologies for the Monitoring of Marine Picoplanktonic Biodiversity Based on rRNA Gene Amplicons. Front. Mar. Sci. 3, 147. https://doi.org/10.3389/fmars.2016.00147

Flo Arcas, E., 2017. Opening the black box of coastal inshore waters in the NW Mediterranean Sea: environmental quality tools and assessment. Doctoral Thesis. http://hdl.handle.net/10261/160058

Flo, E., Garcés, E., Camp, J., 2019. Land Uses Simplified Index ( LUSI ): Determining Land Pressures and Their Link With Coastal Eutrophication. Front. Mar. Sci. 6, 118. https://doi.org/10.3389/fmars.2019.00018

Flo, E., Garcés, E., Manzanera, M., Camp, J., 2011. Coastal inshore waters in the NW Mediterranean: Physicochemical and biological characterization and management implications. Estuar. Coast. Shelf Sci. 93, 279-289. https://doi.org/10.1016/j.ecss.2011.04.002

Frenken, T., Alacid, E., Berger, S.A., Bourne, E.C., Gerphagnon, M., Grossart, H.P., Gsell, A.S., Ibelings, B.W., Kagami, M., Küpper, F.C., Letcher, P.M., Loyau, A., 
Miki, T., Nejstgaard, J.C., Rasconi, S., Reñé, A., Rohrlack, T., Rojas-Jimenez, K., Schmeller, D.S., Scholz, B., Seto, K., Sime-Ngando, T., Sukenik, A., Van de Waal, D.B., Van den Wyngaert, S., Van Donk, E., Wolinska, J., Wurzbacher, C., Agha, R., 2017. Integrating chytrid fungal parasites into plankton ecology: research gaps and needs. Environ. Microbiol. 19, 3802-3822. https://doi.org/10.1111/1462-2920.13827

Fuhrman, J.A., Cram, J.A., Needham, D.M., 2015. Marine microbial community dynamics and their ecological interpretation. Nat. Rev. Microbiol. 13, 133-146. https://doi.org/10.1038/nrmicro3417

Galand, P.E., Lucas, S., Fagervold, S.K., Peru, E., Pruski, A.M., Vétion, G., Dupuy, C., Guizien, K., 2016. Disturbance increases microbial community diversity and production in marine sediments. Front. Microbiol. 7, 1-11. https://doi.org/10.3389/fmicb.2016.01950

Gall, S.C., Thompson, R.C., 2015. The impact of debris on marine life. Mar. Pollut. Bull. 92, 170-179. https://doi.org/10.1016/j.marpolbul.2014.12.041

Garrido, L., Sánchez, O., Ferrera, I., Tomàs, N., Mas, J., 2014. Dynamics of microbial diversity profiles in waters of different qualities. Approximation to an ecological quality indicator. Sci. Total Environ. 468-469, 1154-1161. https://doi.org/10.1016/j.scitotenv.2013.08.065

Gasol, J.M., Cardelús, C., Morán, X.A.G., Balagué, V., Forn, I., Marrasé, C., Massana, R., Pedrós-alió, C., Sala, M.M., Simó, R., Vaqué, D., Estrada, M., 2016. Seasonal patterns in phytoplankton photosynthetic parameters and primary production at a coastal NW Mediterranean site. Sci. Mar. 80S1, 63-77.

https://doi.org/10.3989/scimar.04480.06E

Gasol, J.M., Kirchman, D.L., 2018. Microbial ecology of the oceans. John Wiley \& Sons.

Ghai, R., Mizuno, C., Picazo, A., Camacho, A., Rodriguez-Valera, F., 2014. Key roles for freshwater Actinobacteria revealed by deep metagenomic sequencing. Mol. Ecol. 23(24), 6073-6090. https://doi.org/10.1111/mec.12985

Giner, C.R., Balagué, V., Krabberød, A.K., Ferrera, I., Reñé, A., Garcés, E., Gasol, J.M., Logares, R., Massana, R., 2019. Quantifying long- term recurrence in planktonic microbial eukaryotes. Mol. Ecol. 28, 923-935. https://doi.org/10.1111/mec.14929

Grasshoff, K., Kremling, K., Ehrhardt, M., 2009. Methods of seawater analysis. John Wiley \& Sons.

Grossart, H.P., Van den Wyngaert, S., Kagami, M., Wurzbacher, C., Cunliffe, M., RojasJimenez, K., 2019. Fungi in aquatic ecosystems. Nat. Rev. Microbiol. 17, 339-354. https://doi.org/10.1038/s41579-019-0175-8

Halpern, B.S., Selkoe, K.A., Micheli, F., Kappel, C. V., 2007. Evaluating and ranking the vulnerability of global marine ecosystems to anthropogenic threats. Conserv. Biol. 21, 1301-1315. https://doi.org/10.1111/j.1523-1739.2007.00752.x

Halpern, B.S., Walbridge, S., Selkoe, K.A., Kappel, C. V., Micheli, F., D’Agrosa, C., Bruno, J.F., Casey, K.S., Ebert, C., Fox, H.E., Fujita, R., Heinemann, D., Lenihan, H.S., Madin, E.M.P., Perry, M.T., Selig, E.R., Spalding, M., Steneck, R., Watson, R., 2008. A global map of human impact on Marine Ecosystems. Science 319, 948953. https://doi.org/10.1126/science.1149345

Herlemann, D.P., Labrenz, M., Jürgens, K., Bertilsson, S., Waniek, J.J., Andersson, A.F., 2011. Transitions in bacterial communities along the $2000 \mathrm{~km}$ salinity gradient of the Baltic Sea. ISME J. 5, 1571-9. https://doi.org/10.1038/ismej.2011.41

Hoegh-Guldberg, O., Bruno, J.F., 2010. The impact of climate change on the world's marine ecosystems. Science 328, 1523-1528.

https://doi.org/10.1126/science.1189930

Holm, S., 1979. A Simple Sequentially Rejective Multiple Test Procedure. Scand. J. Stat. 6, 65-70. https://www.jstor.org/stable/4615733 
Hummel, H., Frost, M., Juanes, J.A., Kochmann, J., Bolde, C.F.C.P., Aneiros, F., Vandenbosch, F., Franco, J.N., Echavarri, B., Guinda, X., Puente, A., Fernández, C., Galván, C., Merino, M., Ramos, E., Fernández, P., Pitacco, V., Alberte, M., Wojcik, D., Grabowska, M., Jahnke, M., Crocetta, F., Carugati, L., Scorrano, S., Fraschetti, S., García, P.P., Sanabria Fernández, J.A., Poromov, A., lurchenko, A., Isachenko, A., Chava, A., Pavloudi, C., Bordeyne, F., Andersen, S.F., Eronat, E.G.T., Cakmak, T., Louizidou, P., Rico, J., Ruci, S., Corta Diego, D., Mendez, S., Rousou, M., De Clippele, L., Eriksson, A., Van Zanten, W., Diamant, A., De Matos, V.K.F., 2015. A comparison of the degree of implementation of marine biodiversity indicators by European countries in relation to the Marine Strategy Framework Directive (MSFD). J. Mar. Biol. Assoc. United Kingdom 95, 1519-1531. https://doi.org/10.1017/S0025315415000235

Liquete, C., Piroddi, C., Drakou, E.G., Gurney, L., Katsanevakis, S., Charef, A., Egoh, B., 2013. Current status and future prospects for the assessment of marine and coastal ecosystem services: a systematic review. PLoS One 8. https://doi.org/10.1371/journal.pone.0067737

Logares, R., 2017. Workflow for Analysing MiSeq Amplicons based on Uparse v1.5. Zenodo10 5281. https://doi.org/10.5281/zenodo.259579

Lumbreras, A., Marques, J.T., Belo, A.F., Cristo, M., Fernandes, M., Galioto, D., Machado, M., Mira, A., Sá-Sousa, P., Silva, R., 2016. Assessing the conservation status of Mediterranean temporary ponds using biodiversity: a new tool for practitioners. Hydrobiologia 782, 187-199.

https://doi.org/10.1016/j.marpolbul.2016.10.050

Magurran, A.E., 1988. Ecological diversity and its measurements. Princet. Univ. Press. New Jersey. 177pp.

Margiotta, F., Balestra, C., Buondonno, A., Casotti, R., D’Ambra, I., Di Capua, I., Gallia, R., Mazzocchi, M.G., Merquiol, L., Pepi, M., Percopo, I., Saggiomo, M., Sarno, D., Zingone, A, 2020. Do plankton reflect the environmental quality status? The case of a post-industrial Mediterranean Bay. Mar. Environ. Res. 104980. https://doi.org/10.1016/j.marenvres.2020.104980

Massana, R., Castresana, J., Balagué, V., Guillou, L., Romari, K., Groisillier, A., Valentin, K., Pedrós-Alió, C., 2004. Phylogenetic and ecological analysis of novel marine stramenopiles. Appl. Environ. Microbiol. 70, 3528-3534. https://doi.org/10.1128/AEM.70.6.3528-3534.2004

Massana, R., Del Campo, J., Sieracki, M.E., Audic, S., Logares, R., Campo, J., Sieracki, M.E., 2014. Exploring the uncultured microeukaryote majority in the oceans: reevaluation of ribogroups within stramenopiles. ISME J. 8, 854-66. https://doi.org/10.1038/ismej.2013.204

Massana, R., Murray, a E., Preston, C.M., DeLong, E.F., 1997. Vertical distribution and phylogenetic characterization of marine planktonic Archaea in the Santa Barbara Channel. Appl. Environ. Microbiol. 63, 50-56. https://doi.org/10.1128/aem.63.1.5056.1997

Nikolenko, S.I., Korobeynikov, A.I., Alekseyev, M.A., 2013. BayesHammer: Bayesian Clustering for Error Correction in Single-Cell Sequencing. BMC Genomics 14. https://doi.org/10.1186/1471-2164-14-S1-S7

Nogales, B., Lanfranconi, M.P., Piña-Villalonga, J.M., Bosch, R., 2011. Anthropogenic perturbations in marine microbial communities. FEMS Microbiol. Rev. 35, 275-298. https://doi.org/10.1111//.1574-6976.2010.00248.x

Nurk, S., Bankevich, A., Antipov, D., Gurevich, A., Korobeynikov, A., Lapidus, A., Prjibelsky, A., Pyshkin, A., Sirotkin, A., Sirotkin, Y., Stepanauskas, R., McLean, J., Lasken, R., Clingenpeel, S.R., Woyke, T., Tesler, G., Alekseyev, M.A., Pevzner, P.A., 2013. Assembling genomes and mini-metagenomes from highly chimeric reads, in: Lecture Notes in Computer Science (Including Subseries Lecture Notes in Artificial Intelligence and Lecture Notes in Bioinformatics). pp. 158-170.

https://doi.org/10.1007/978-3-642-37195-0_13 
Obiol, A., Giner, C.R., Sánchez, P., Duarte, C.M., Acinas, S.G., Massana, R., 2020. A metagenomic assessment of microbial eukaryotic diversity in the global ocean. Mol. Ecol. Resour. 1-14. https://doi.org/10.1111/1755-0998.13147

Pawlowski, J., Esling, P., Lejzerowicz, F., Cedhagen, T., Wilding, T.A., 2014. Environmental monitoring through protist next-generation sequencing metabarcoding: Assessing the impact of fish farming on benthic foraminifera communities. Mol. Ecol. Resour. 14, 1129-1140. https://doi.org/10.1111/17550998.12261

Pawlowski, J., Kelly-Quinn, M., Altermatt, F., Apothéloz-Perret-Gentil, L., Beja, P., Boggero, A., Borja, A., Bouchez, A., Cordier, T., Domaizon, I., Feio, M.J., Filipe, A.F., Fornaroli, R., Graf, W., Herder, J., van der Hoorn, B., Iwan Jones, J., SagovaMareckova, M., Moritz, C., Barquín, J., Piggott, J.J., Pinna, M., Rimet, F., Rinkevich, B., Sousa-Santos, C., Specchia, V., Trobajo, R., Vasselon, V., Vitecek, S., Zimmerman, J., Weigand, A., Leese, F., Kahlert, M., 2018. The future of biotic indices in the ecogenomic era: Integrating (e)DNA metabarcoding in biological assessment of aquatic ecosystems. Sci. Total Environ. 637-638, 1295-1310. https://doi.org/10.1016/i.scitotenv.2018.05.002

Pearman, J.K., Afandi, F., Hong, P., Carvalho, S., 2018. Plankton community assessment in antrophogenic-impacted oligotrophic coastal regions. Environ. Sci. Pollut. Res. 25, 31017-31030. https://doi.org/10.1007/s11356-018-3072-1

Polz, M.F., Cavanaugh, C.M., 1998. Bias in template-to-product ratios in multitemplate PCR. Appl. Environ. Microbiol. 64, 3724-3730.

https://aem.asm.org/content/64/10/3724

R Development Core Team. 2015. https://www.r-project.org/

Reñé, A., Satta, C.T., Garcés, E., Massana, R., Zapata, M., Anglès, S., Camp, J., 2011. Gymnodinium litoralis sp. nov.(Dinophyceae), a newly identified bloom-forming dinoflagellate from the NW Mediterranean Sea. Harmful Algae 12, 11-25. https://doi.org/10.1016/.hal.2011.08.008

Rodellas, V., Garcia-Orellana, J., Tovar-Sánchez, A., Basterretxea, G., López-Garcia, J.M., Sánchez-Quiles, D., Garcia-Solsona, E., Masqué, P., 2014. Submarine groundwater discharge as a source of nutrients and trace metals in a Mediterranean bay (Palma Beach, Balearic Islands). Mar. Chem. 160, 56-66. https://doi.org/10.1016/J.MARCHEM.2014.01.007

Sokal, R.R., Rohlf, F.J., 1995. The arcsine transformation, in: Biometry. WH Freeman New York, New York.

Stoeck, T., Bass, D., Nebel, M., Christen, R., Jones, M.D.M., Breiner, H.W., Richards, T.A., 2010. Multiple marker parallel tag environmental DNA sequencing reveals a highly complex eukaryotic community in marine anoxic water. Mol. Ecol. 19, 21-31. https://doi.org/10.1111/j.1365-294X.2009.04480.x

Stoeck, T., Frühe, L., Forster, D., Cordier, T., Martins, C.I.M., Pawlowski, J., 2018. Environmental DNA metabarcoding of benthic bacterial communities indicates the benthic footprint of salmon aquaculture. Mar. Pollut. Bull. 127, 139-149. https://doi.org/10.1016/j.marpolbul.2017.11.065

Tovar-Sánchez, A., Basterretxea, G., Rodellas, V., Sánchez-Quiles, D., García-Orellana, J., Masqué, P., et al., 2014. Contribution of groundwater discharge to the coastal dissolved nutrients and trace metal concentrations in Majorca Island: karstic vs detrital systems. Environ. Sci. Technol. 48, 11819-11827. https://doi.org/10.1021/es502958t

Tragin, M., Vaulot, D., 2018. Green microalgae in marine coastal waters: The Ocean Sampling Day (OSD) dataset. Sci. Rep. 8, 1-12. https://doi.org/10.1038/s41598$\underline{018-32338-w}$ 
Table 1. Values (average \pm standard deviation, minimum to maximum) of the FLU and FAN impact indices as well as of the measured environmental variables in each sampling area.

\begin{tabular}{|c|c|c|c|c|c|c|c|c|c|c|c|}
\hline Site & $\begin{array}{l}\text { Number } \\
\text { of } \\
\text { samples }\end{array}$ & $\begin{array}{c}\text { Temperature } \\
\left({ }^{\circ} \mathrm{C}\right)\end{array}$ & $\begin{array}{l}\text { Salinity } \\
\text { (psu) }\end{array}$ & $\begin{array}{l}\mathrm{PO}_{4}{ }^{3+} \\
(\mu \mathrm{M})\end{array}$ & $\begin{array}{l}\mathrm{NH}_{4}^{+} \\
(\mu \mathrm{M})\end{array}$ & $\begin{array}{l}\mathrm{NO}_{2}^{-} \\
(\mu \mathrm{M})\end{array}$ & $\begin{array}{l}\mathrm{NO}_{3}^{-} \\
(\mu \mathrm{M})\end{array}$ & $\begin{array}{c}\mathrm{Si} \\
(\mu \mathrm{M})\end{array}$ & $\begin{array}{c}\text { Chl a } \\
\text { concentration } \\
\left(\mu \mathrm{g} \cdot \mathrm{L}^{-1}\right)\end{array}$ & FLU & FAN \\
\hline Alfacs & 4 & $\begin{array}{c}26.5 \pm 0.4 \\
(26.0 \text { to } 26.8)\end{array}$ & $\begin{array}{c}35.85 \pm 0.42 \\
(35.30 \text { to } \\
36.3)\end{array}$ & $\begin{array}{c}0.16 \pm 0.02 \\
(0.13 \text { to } 0.18)\end{array}$ & $\begin{array}{c}0.84 \pm 0.72 \\
(0.04 \text { to } \\
1.67)\end{array}$ & $\begin{array}{c}0.12 \pm 0.04 \\
(0.09 \text { to } 0.18)\end{array}$ & $\begin{array}{c}0.60 \pm 0.40 \\
(0.33 \text { to } 1.19)\end{array}$ & $\begin{array}{c}8.08 \pm 4.37 \\
(2.65 \text { to } \\
11.88)\end{array}$ & $\begin{array}{c}1.96 \pm 0.45 \\
(1.52 \text { to } 2.39)\end{array}$ & $\begin{array}{c}60.1 \pm 14.6 \\
(42.9 \text { to } 77.2)\end{array}$ & $\begin{array}{c}-22.2 \pm 6.0 \\
(-29.5 \text { to }-15.4)\end{array}$ \\
\hline Barcelona & 23 & $\begin{array}{c}23.1 \pm 1.8 \\
(20.3 \text { to } 26.0)\end{array}$ & $\begin{array}{c}37.79 \pm 0.19 \\
(37.04 \text { to } \\
38.01)\end{array}$ & $\begin{array}{c}0.12 \pm 0.08 \\
(0.02 \text { to } 0.35)\end{array}$ & $\begin{array}{c}1.15 \pm 1.12 \\
(0.12 \text { to } \\
4.01)\end{array}$ & $\begin{array}{c}0.21 \pm 0.21 \\
(0.00 \text { to } 0.98)\end{array}$ & $\begin{array}{c}0.73 \pm 0.84 \\
(0.04 \text { to } 3.91)\end{array}$ & $\begin{array}{c}1.16 \pm 2.01 \\
(0.10 \text { to } 9.17)\end{array}$ & $\begin{array}{l}0.79 \pm 0.49 \\
0.15 \text { to } 1.82\end{array}$ & $\begin{array}{c}7.7 \pm 4.4 \\
(2.4 \text { to } 24.2)\end{array}$ & $\begin{array}{c}-1.9 \pm 2.8 \\
(-9.8 \text { to } 4.1)\end{array}$ \\
\hline Blanes & 35 & $\begin{array}{c}22.5 \pm 2.5 \\
(16.5 \text { to } 26.2)\end{array}$ & $\begin{array}{c}37.59 \pm 0.71 \\
(35.08 \text { to } \\
38.17)\end{array}$ & $\begin{array}{c}0.10 \pm 0.06 \\
(0.02 \text { to } 0.23)\end{array}$ & $\begin{array}{l}1.06 \pm 0.83 \\
\text { (0.1 to } 3.48)\end{array}$ & $\begin{array}{c}0.13 \pm 0.16 \\
(0.01 \text { to } 0.87)\end{array}$ & $\begin{array}{c}0.34 \pm 0.28 \\
(0.03 \text { to } 1.38)\end{array}$ & $\begin{array}{c}0.87 \pm 0.54 \\
(0.04 \text { to } 2.22)\end{array}$ & $\begin{array}{l}0.33 \pm 0.20 \\
0.02 \text { to } 0.86\end{array}$ & $\begin{array}{c}11.7 \pm 16.1 \\
(-0.85 \text { to } 69.4)\end{array}$ & $\begin{array}{c}-4.0 \pm 6.5 \\
(-27.1 \text { to } 3.1)\end{array}$ \\
\hline L'Estartit & 10 & $\begin{array}{c}21.4 \pm 0.2 \\
(20.9 \text { to } 21.7)\end{array}$ & $\begin{array}{c}36.62 \pm 0.79 \\
(35.14 \text { to } \\
37.47)\end{array}$ & $\begin{array}{c}0.41 \pm 0.40 \\
(0.11 \text { to } 1.23)\end{array}$ & $\begin{array}{c}0.23 \pm 0.20 \\
(0.03 \text { to } \\
0.62)\end{array}$ & $\begin{array}{c}0.25 \pm 0.23 \\
(0.07 \text { to } 0.79)\end{array}$ & $\begin{array}{c}7.90 \pm 10.30 \\
(0.18 \text { to } \\
31.27)\end{array}$ & $\begin{array}{c}15.15 \pm 17.09 \\
(1.36 \text { to } \\
52.96)\end{array}$ & $\begin{array}{l}1.29 \pm 1.05 \\
0.21 \text { to } 3.65\end{array}$ & $\begin{array}{c}56.9 \pm 44.7 \\
(15.5 \text { to } 144.4)\end{array}$ & $\begin{array}{c}-18.1 \pm 11.4 \\
(-38.6 \text { to }-6.8)\end{array}$ \\
\hline $\begin{array}{l}\text { L'Hospitalet } \\
\text { de l'Infant }\end{array}$ & 10 & $\begin{array}{c}24.6 \pm 0.3 \\
(24.1 \text { to } 25.1)\end{array}$ & $\begin{array}{c}36.65 \pm 0.42 \\
(35.53 \text { to } \\
37.14)\end{array}$ & $\begin{array}{c}0.13 \pm 0.02 \\
(0.11 \text { to } 0.17)\end{array}$ & $\begin{array}{c}0.24 \pm 0.18 \\
(0.02 \text { to } \\
0.57)\end{array}$ & $\begin{array}{c}0.12 \pm 0.02 \\
(0.08 \text { to } 0.15)\end{array}$ & $\begin{array}{c}0.88 \pm 0.78 \\
(0.32 \text { to } 2.82)\end{array}$ & $\begin{array}{c}0.81 \pm 0.70 \\
(0.32 \text { to } 2.14)\end{array}$ & $\begin{array}{l}1.01 \pm 0.39 \\
0.67 \text { to } 1.80\end{array}$ & $\begin{array}{c}34.0 \pm 10.8 \\
(22.0 \text { to } 62.4)\end{array}$ & $\begin{array}{c}-13.8 \pm 4.2 \\
(-25.0 \text { to }-9.5)\end{array}$ \\
\hline Palma & 11 & $\begin{array}{c}29.4 \pm 0.7 \\
(28.0 \text { to } 30.8)\end{array}$ & $\begin{array}{c}37.6 \pm 0.05 \\
(37.46 \text { to } \\
37.64)\end{array}$ & $\begin{array}{c}0.17 \pm 0.05 \\
(0.11 \text { to } 0.26)\end{array}$ & $\begin{array}{c}0.29 \pm 0.28 \\
(0.06 \text { to } \\
1.02)\end{array}$ & $\begin{array}{c}0.10 \pm 0.14 \\
(0.02 \text { to } 0.51)\end{array}$ & $\begin{array}{c}0.96 \pm 1.16 \\
(0.06 \text { to } 4.04)\end{array}$ & $\begin{array}{c}1.02 \pm 0.40 \\
(0.72 \text { to } 2.06)\end{array}$ & $\begin{array}{l}0.67 \pm 0.48 \\
0.29 \text { to } 1.77\end{array}$ & $\begin{array}{c}12.7 \pm 1.58 \\
(10.8 \text { to } 15.3)\end{array}$ & $\begin{array}{c}-5.1 \pm 0.4 \\
(-5.5 \text { to }-4.1)\end{array}$ \\
\hline
\end{tabular}


Table 2. Potential indicator taxonomic groups identified by significant IndVal for the various categories and the FLU and FAN impact indices that each sample falls into. Pico (picoplankton) corresponds to the $0.2-3 \mu \mathrm{m}$ fraction; nano (nanoplankton) corresponds to the $3-20 \mu \mathrm{m}$ fraction. Abundance (\%) indicates the mean relative abundance of that taxon in the corresponding fraction.

\begin{tabular}{|c|c|c|c|c|c|c|c|}
\hline Domain & $\begin{array}{c}\text { Size } \\
\text { Fractio } \\
\mathbf{n} \\
\end{array}$ & Taxonomic group & $\begin{array}{c}\text { Rel. } \\
\text { Abund. } \\
(\%)\end{array}$ & $\begin{array}{c}\text { Variabl } \\
\text { e }\end{array}$ & $\begin{array}{c}\text { Categor } \\
y\end{array}$ & $\underset{I}{\operatorname{IndVa}}$ & P-value \\
\hline \multirow[t]{9}{*}{$\begin{array}{c}\text { Prokaryote } \\
\mathrm{s}\end{array}$} & pico & Actinobacteria & 4.37 & FAN & Low & 0.59 & $3.0 e^{-04}$ \\
\hline & pico & Sphingobacteriia & 2.05 & FAN & Low & 0.48 & $5.0 e^{-04}$ \\
\hline & pico & Actinobacteria & 4.37 & FLU & High & 0.60 & $3.0 e^{-04}$ \\
\hline & pico & Sphingobacteriia & 2.05 & FLU & High & 0.49 & $3.0 e^{-04}$ \\
\hline & nano & Sphingobacteriia & 5.68 & FAN & Low & 0.53 & $3.0 e^{-04}$ \\
\hline & nano & Planctomycetes & 2.42 & FAN & Low & 0.46 & $1.5 e^{-03}$ \\
\hline & nano & Flavobacteriia & 15.05 & FLU & Medium & 0.41 & $2.4 e^{-02}$ \\
\hline & nano & Sphingobacteriia & 5.68 & FLU & High & 0.53 & $3.0 e^{-04}$ \\
\hline & nano & Planctomycetes & 2.42 & FLU & High & 0.44 & $1.4 e^{-02}$ \\
\hline \multirow[t]{6}{*}{ Eukaryotes } & pico & $\begin{array}{c}\text { Chlorodendrophycea } \\
\text { e (Archaeplastida) }\end{array}$ & 4.76 & FAN & Low & 0.73 & $5.8 e^{-03}$ \\
\hline & pico & $\begin{array}{c}\text { Chlorodendrophycea } \\
\text { e (Archaeplastida) }\end{array}$ & 4.76 & FLU & High & 0.68 & $3.4 e^{-02}$ \\
\hline & pico & Telonema (Hacrobia) & 0.67 & FLU & Low & 0.52 & $3.4 e^{-02}$ \\
\hline & pico & Cercozoa (Rhizaria) & 1.7 & FLU & Low & 0.55 & $1.9 e^{-03}$ \\
\hline & pico & $\begin{array}{c}\text { MAST_3 } \\
\text { (Stramenopiles) }\end{array}$ & 1.94 & FLU & Low & 0.51 & $1.2 \mathrm{e}^{-02}$ \\
\hline & pico & $\begin{array}{c}\text { MAST_4 } \\
\text { (Stramenopiles) }\end{array}$ & 0.77 & FLU & Low & 0.54 & $2.9 e^{-02}$ \\
\hline
\end{tabular}


Supplementary Table 1. Table showing the results of an integrated assessment of coastal waters using a dataset from the Catalan Water Agency (ACA) from 2011 to 2016 and thus corresponding to the 6-year evaluation period mandated by the Water Framework Directive to assess water status*. The data from Palma de Mallorca correspond to a report from the Balearic Islands Government**. The information was used to choose the study area included in this work. FAN and FLU indexes, LUSI and Chlorophyll a (Chl-a) concentration were applied to a dataset from 2011 to 2016 of the Catalan water bodies (WBs) and to the 2009-2015 period for the Balearic coast. The LUSI method assesses the continental pressures on coastal waters, which are linked to continental influences (Flo et al., 2019). The FAN and FLU indexes method assesses the water quality, the anthropogenic component of the trophic state, the fluviality and the continental influences on coastal waters. WBs code and name are indicated, together with the salinity and Chl-a concentration $\left(\mu \mathrm{L}^{-1}\right)$.

\begin{tabular}{|c|c|c|c|c|c|c|c|c|c|}
\hline WB code & WB name & $\begin{array}{c}\text { Correspondence } \\
\text { to this work }\end{array}$ & LUSI & $\begin{array}{l}\text { FAN } \\
\text { INDEX }\end{array}$ & $\begin{array}{l}\text { FLU } \\
\text { INDEX }\end{array}$ & SALINITY & Chl-a & FLUVIALITY & $\begin{array}{l}\text { CONTINENTAL } \\
\text { INFLUENCES }\end{array}$ \\
\hline C11 & $\begin{array}{c}\text { Torroella de } \\
\text { Montgri }\end{array}$ & L'Estartit & 6.25 & 0.75 & 0.88 & 34.09 & 0.9 & High & Fluvial influence \\
\hline C15 & $\begin{array}{l}\text { Blanes-Pineda de } \\
\text { Mar }\end{array}$ & Blanes & 4 & 1 & 0.75 & 36.99 & 0.71 & Low & None \\
\hline C19 & $\begin{array}{c}\text { Sant Adrià de } \\
\text { Besòs-Barceloneta }\end{array}$ & Barcelona & 4 & 0.13 & 0.63 & 37.43 & 1.16 & Medium & Mixed \\
\hline C31 & $\begin{array}{l}\text { Vandellós i } \\
\text { L'Hospitalet de } \\
\text { l'Infant }\end{array}$ & $\begin{array}{l}\text { L'Hospitalet de } \\
\text { I'Infant }\end{array}$ & 2 & 1 & 1 & 37.71 & 0.65 & Medium & None \\
\hline T03 & $\begin{array}{l}\text { Badia } \\
\text { Alfacs }\end{array}$ & Alfacs & 6.25 & 0.75 & 0.13 & 33.39 & 6.45 & Very high & Fluvial influence \\
\hline MAMC15M3 & $\begin{array}{l}\text { Palma de } \\
\text { Mallorca }\end{array}$ & Palma & 6 & & & 36 & 0.9 & Medium & Mixed \\
\hline
\end{tabular}

*Data extracted from Flo (2017)

** Plan Hidrológico de las Illes Balears2015-2021 Memoria, Govern de les Illes Balears. http://observatoriaigua.uib.es/repositori/phib 2015 memoria.pdf 
Supplementary Table 2. Taxa displaying significant correlation values between their relative abundance and the impact indices or nutrient concentrations measured in sampled waters. Size fraction indicates picoplankton (pico) or nanoplankton (nano). Abundance $(\%)$ represents the mean relative abundance of that taxa in that size fraction. Pearson correlations and $p$-values are shown.

\begin{tabular}{|c|c|c|c|c|c|c|}
\hline \multicolumn{2}{|c|}{ Taxonomic Group } & Size fraction & Abundance (\%) & Variable & Correlation & p-value \\
\hline \multirow[t]{2}{*}{ Prokaryotes } & Actinobacteria & pico & 4.37 & FAN Index & 0.60 & 2.1E-19 \\
\hline & Actinobacteria & pico & 4.37 & FLU Index & 0.59 & 7.7E-19 \\
\hline \multirow[t]{3}{*}{ Eukaryotes } & BasalFungi (Opisthokonta) & nano & 0.38 & $\mathrm{PO}_{4}^{3-}$ & 0.50 & $2.5 \mathrm{E}-13$ \\
\hline & BasalFungi (Opisthokonta) & nano & 0.38 & $\mathrm{NO}_{3}^{-}$ & 0.74 & $1.6 \mathrm{E}-26$ \\
\hline & BasalFungi (Opisthokonta) & nano & 0.38 & $\mathrm{Si}$ & 0.62 & 8.1E-19 \\
\hline
\end{tabular}


Supplementary Table 3. OTUs showing significant Pearson correlation values between their relative abundance in the nanoplankton fraction and the nutrient loads measured in sampled waters.

\begin{tabular}{cccccc}
\hline OTU & Rel. Ab. (\%) & Variable & Correlation & p-value & Taxonomy \\
\hline OTU9 & 0.5 & $\mathrm{PO}_{4}{ }^{3-}$ & 0.55 & $2.33 \mathrm{E}-15$ & $\begin{array}{c}\text { Alveolata;Dinoflagellata;Dinophyceae;Gymnodiniphycidae; } \\
\text { Gymnodinium litoralis }\end{array}$ \\
OTU9 & 0.5 & $\mathrm{NO}_{3}{ }^{-}$ & 0.74 & $6.44 \mathrm{E}-27$ & $\begin{array}{c}\text { Alveolata;Dinoflagellata;Dinophyceae;Gymnodiniphycidae; } \\
\text { Gymnodinium litoralis }\end{array}$ \\
OTU9 & 0.5 & $\mathrm{Si}$ & 0.52 & $3.31 \mathrm{E}-14$ & $\begin{array}{c}\text { Alveolata;Dinoflagellata;Dinophyceae;Gymnodiniphycidae; } \\
\text { Gymnodinium litoralis }\end{array}$ \\
\hline
\end{tabular}




\section{Figure Legends}

Figure 1. Map of the NW Mediterranean area showing the sampled areas (source: QGIS Geographic Information System, http://qgis.osgeo.org).

Figure 2. Box plots of the FLU and FAN impact indices for each sampling location. Letters shown in the boxes represent the results of a Tukey HSD test. Areas not connected by the same letter are significantly different $(p<0.05)$.

Figure 3. Box plots of prokaryotic richness (Chao1) and diversity (Shannon) indices depending on the categories of the FLU and FAN impact indices that each sample falls into (Low, Medium, High). Two plankton size fractions were analyzed separately (nano: nanoplankton; pico: picoplankton). No significant differences were found (ANOVA, $\mathrm{p}<0.05)$.

Figure 4. Box plots of eukaryotic richness (Chao1) and diversity (Shannon) indices depending on the categories of the FLU and FAN impact indices that each sample falls into (Low, Medium, High). Two plankton size fractions were analyzed separately (nano: nanoplankton; pico: picoplankton). *Asterisks indicate that differences for that category and size fraction were significant (Tukey HSD test at $p<0.05$ ).

Figure 5. Bar plots showing the relative abundances of prokaryotic (left) and eukaryotic (right) taxa depending on the FLU and FAN impact index categories (Low, Medium or High). Two plankton size fractions were analyzed separately (nano: nanoplankton; pico: picoplankton).

Figure 6. Box plot showing the differences in the Actinobacteria / Rickettsiales ratio in the picoplankton fraction along the FLU and FAN index categories. 


\section{Supplementary Figure Legends}

Figure S1. FLU and FAN impact index values for each sample grouped by the index category. Each sample is colored according to the sampling area.

Figure S2. Non-metric multidimensional scaling (nMDS) plots based on Bray-Curtis distances of OTU composition with vector overlays of the environmental factors (only statistically significant variables are shown). $R^{2}$ and $p$ values correspond to the results of the adonis test. pico: picoplankton fraction, nano: nanoplankton fraction.

Figure S3. Box plots of prokaryotic and eukaryotic taxa showing significant differences (ANOVA, $p<0.05$ ) in the normalized relative abundances depending on the categories of the devised FLU and FAN indices (Low, Medium or High). The plankton size fraction is also indicated (nano: nanoplankton; pico: picoplankton).

Figure S4. FLU and FAN values for each sample depending on the distance to the coast at which the samples were collected. Samples are colored by sampling area. Alfacs Bay samples are not shown since those samples belong to an estuary. 


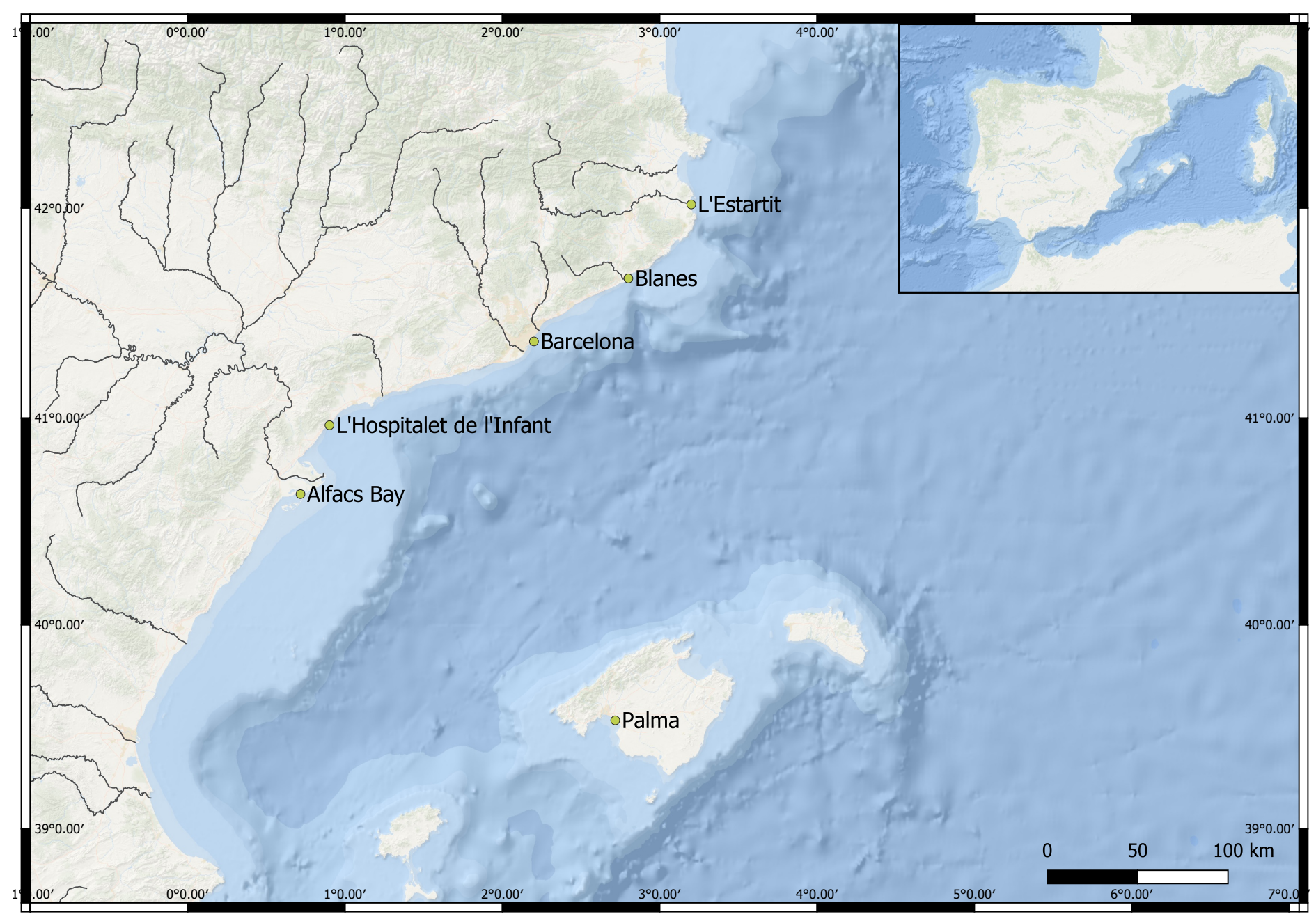



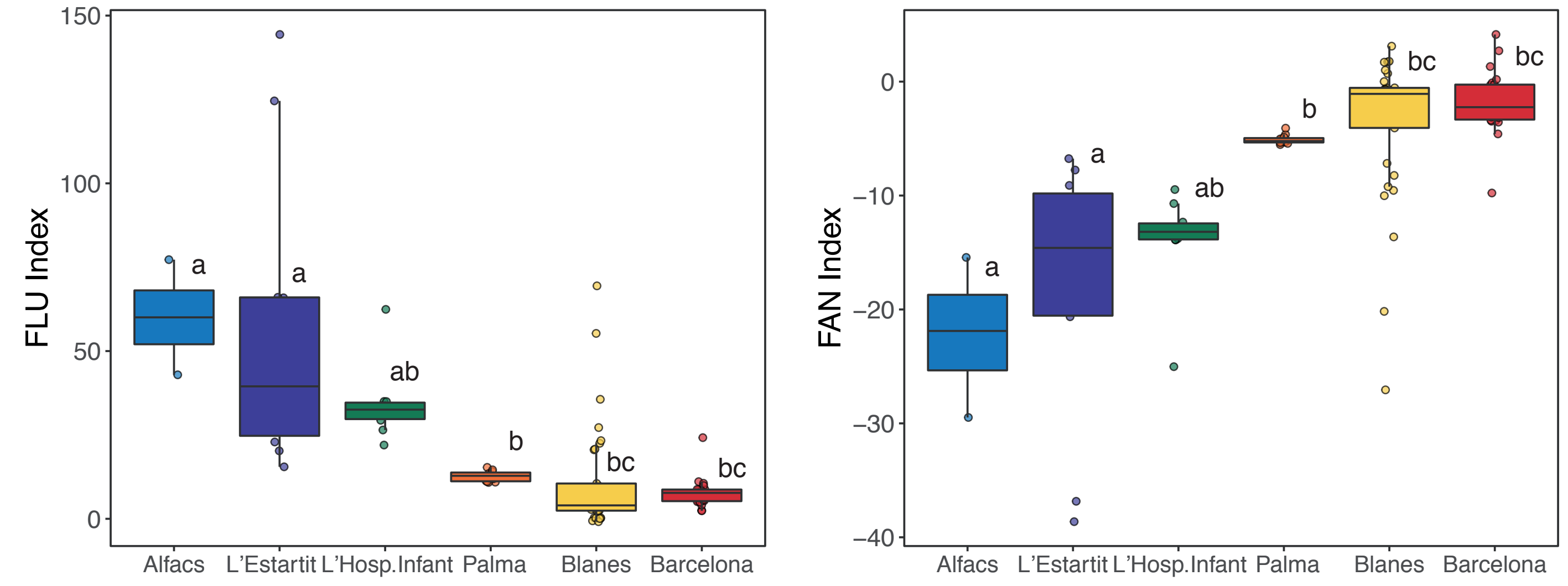

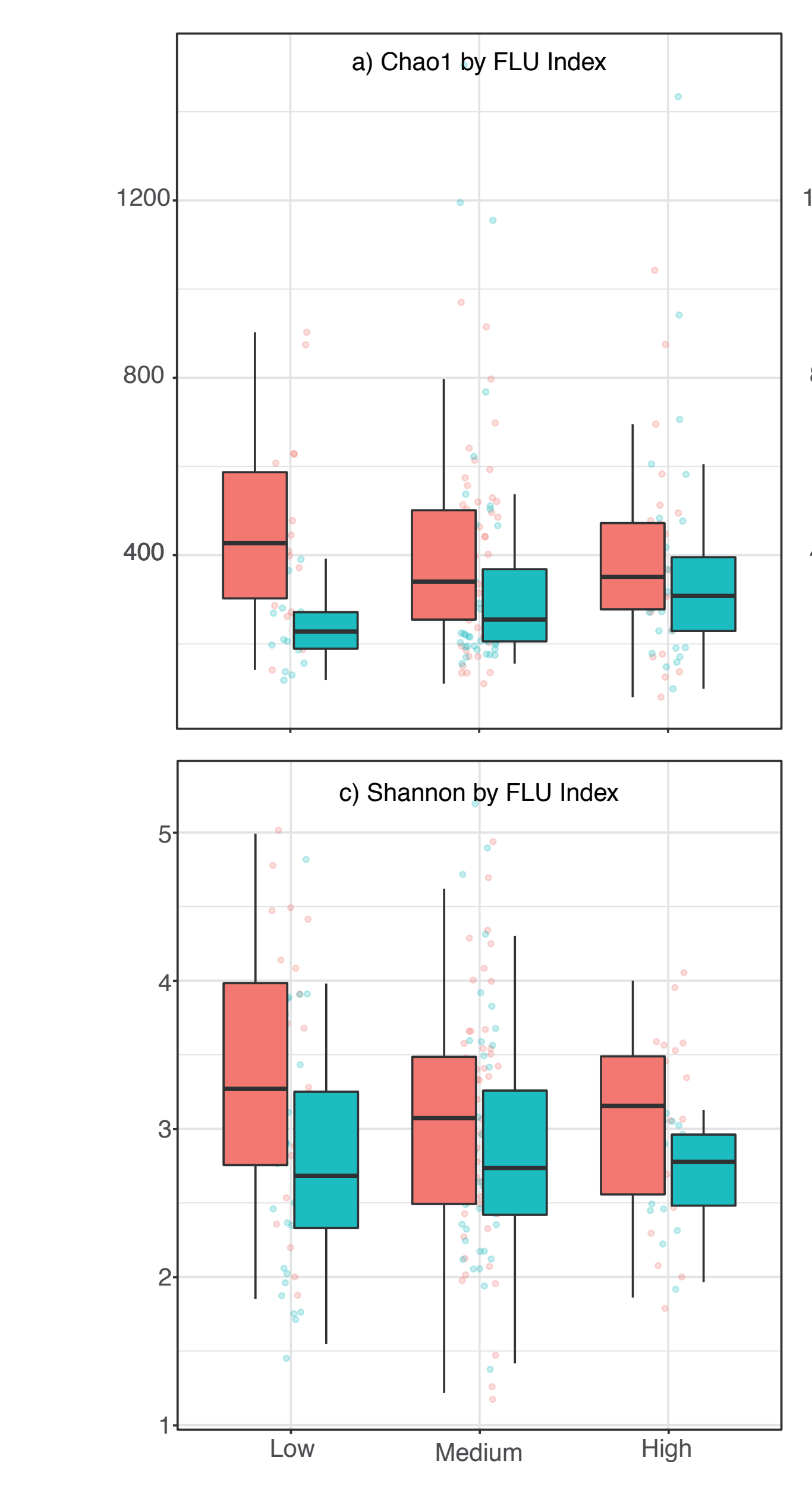
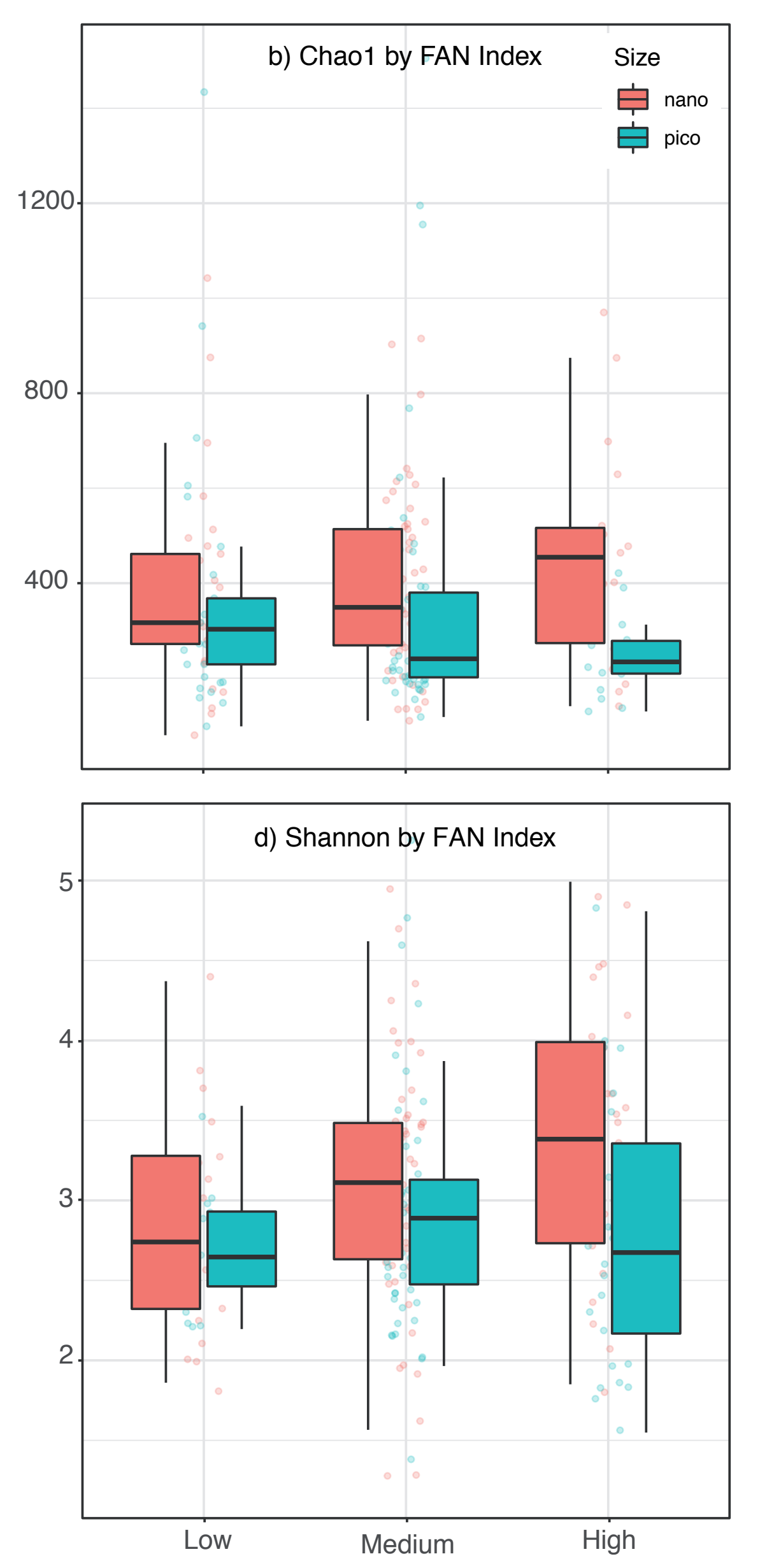

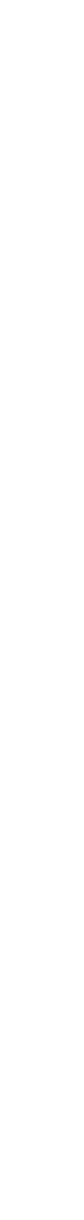



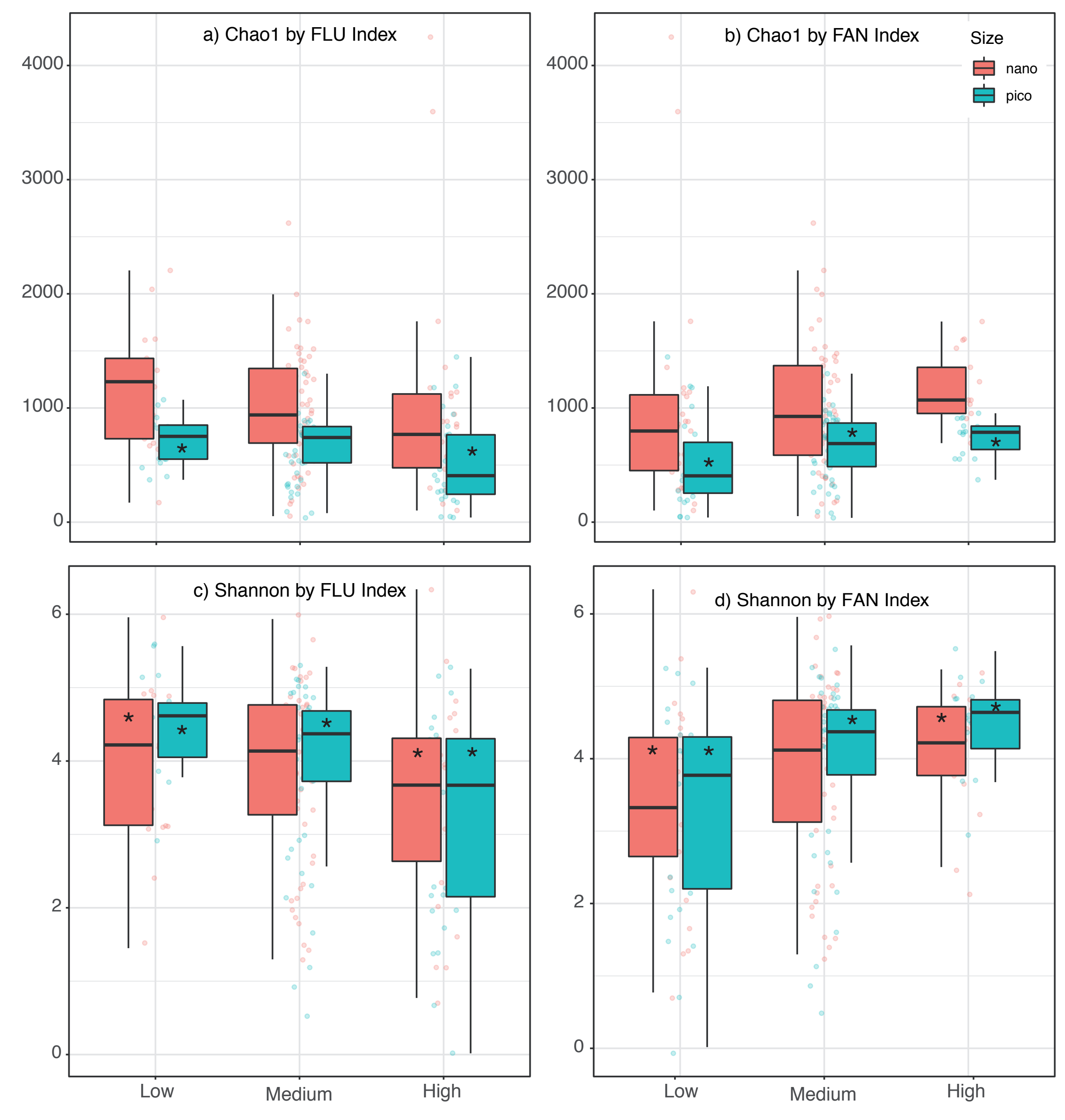

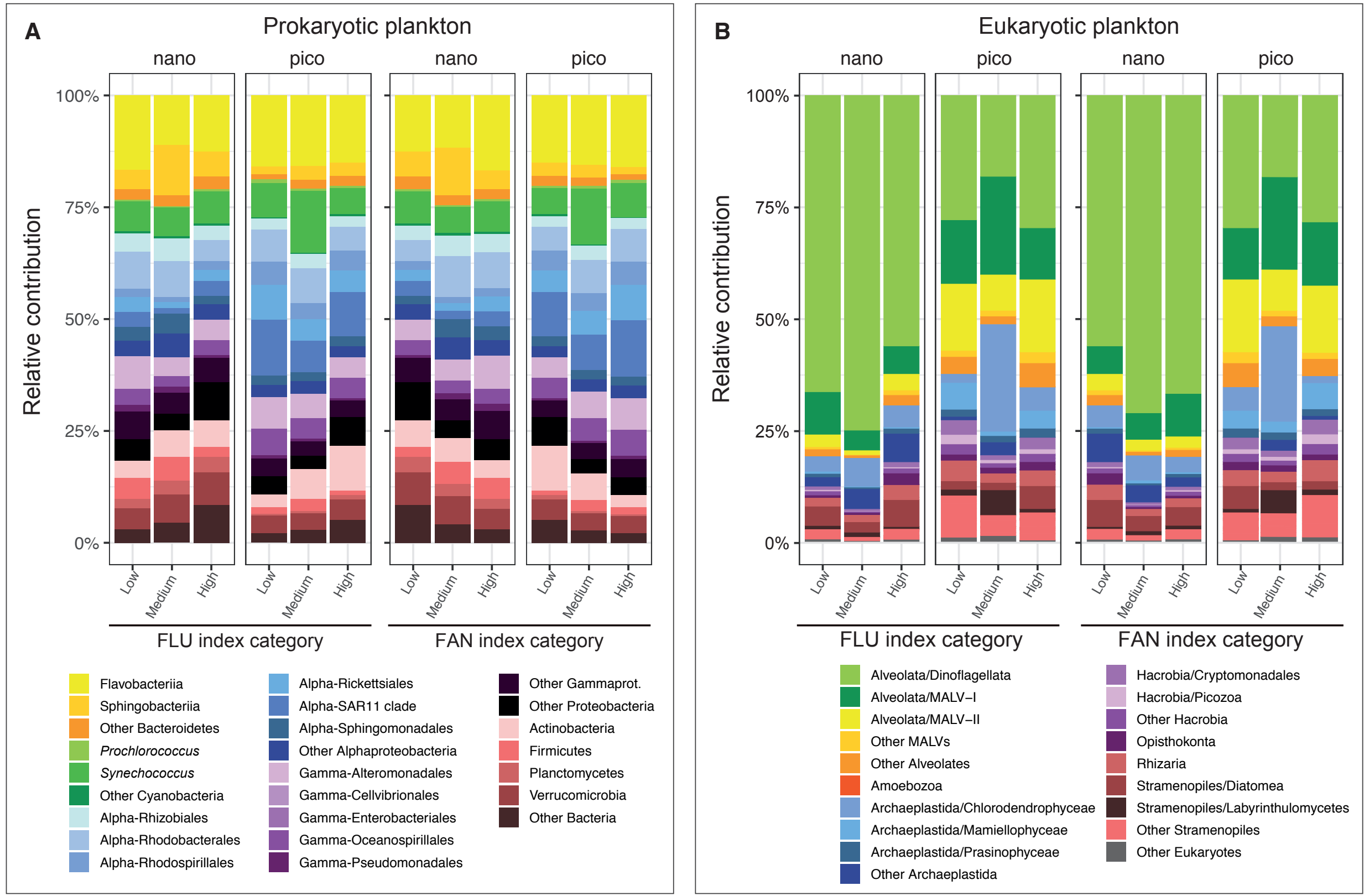

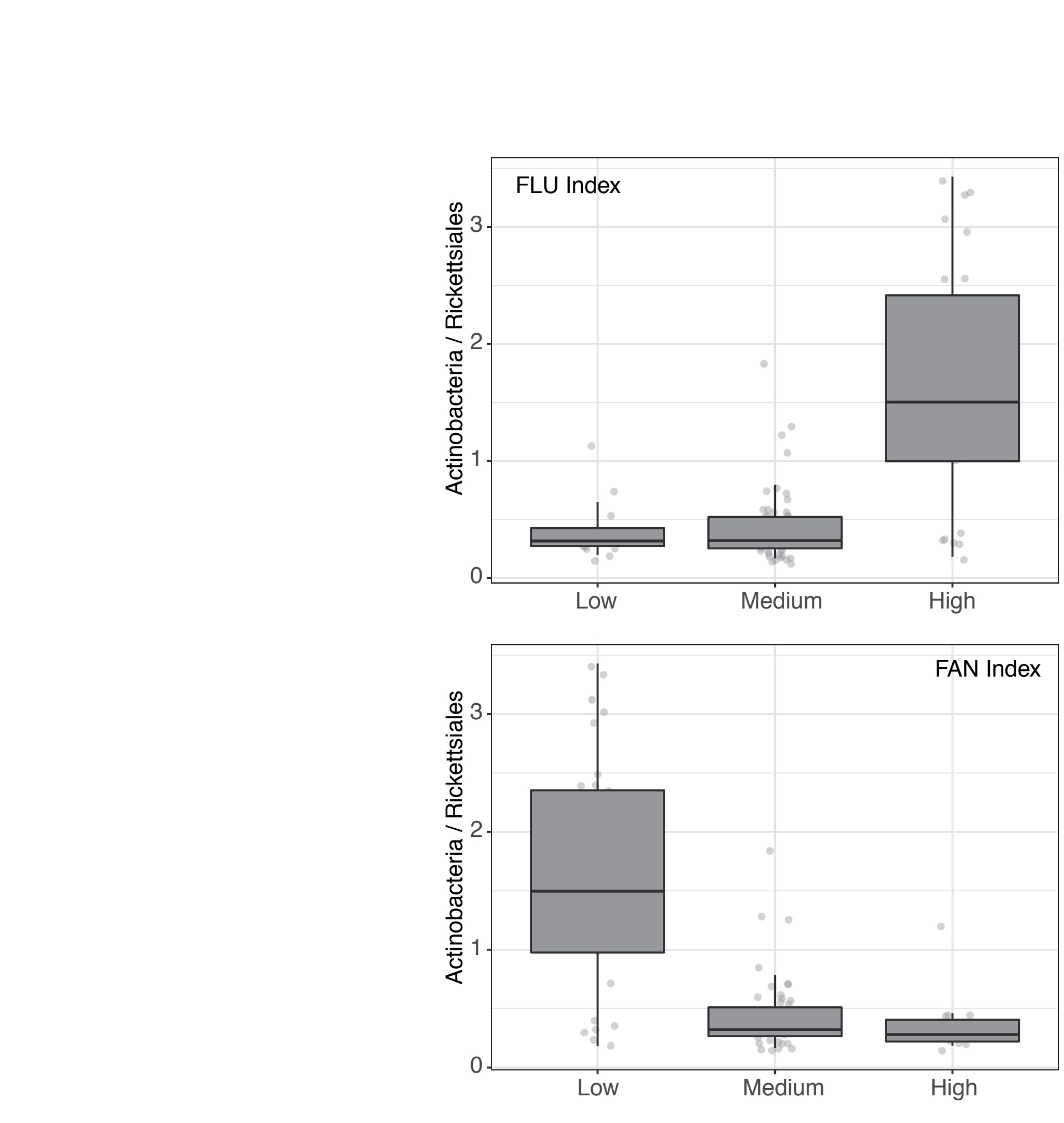
Supplementary Data
Click here to downloa

Click here to download Supplementary Data: SupplementaryData.pdf

Click here to download Supplementary Data: SupplementaryDatapdf

, 


\section{Author statement}

Isabel Ferrera: Conceptualization, Methodology, Investigation, Validation, Writing original draft, Reviewing, Editing; Albert Reñé: Conceptualization, Methodology, Investigation, Reviewing, Editing; David Funosas: Software, Analysis, Writing; Jordi Camp: Conceptualization, Resources, Reviewing; Ramon Massana: Resources, Reviewing; Josep M Gasol: Resources, Reviewing; Esther Garcés:

Conceptualization, Resources, Reviewing, Editing 